\title{
La destruición de Numancia de Miguel de Cervantes según Rafael Alberti y Federico García Lorca: dos propuestas teatrales alternativas
}

\author{
Sergio ARLANDis*
}

\begin{abstract}
Resumen
Las lecturas que hicieron algunos escritores de la generación del 27 sobre nuestros clásicos han tenido una amplia gama de interpretaciones al respecto. El caso es que Miguel de Cervantes fue uno de esos autores retomados en los albores de la Guerra Civil española y una obra suya, La destruición de Numancia, pronto fue considerada como uno de los referentes ideológicos de los dos bandos. Este trabajo vendrá a poner el acento en un debate concreto: ahondar en el modo en el que dos escritores tan próximos como Alberti y García Lorca, asimilaron, de manera tan distinta, ese legado cervantino, uno llevando hasta su máxima politización la tragedia clásica con su puesta en escena en Madrid; y el otro - y esto no ha sido estudiado aún- por cómo intentó apartarse de ese sello político quedándose con toda la estructura teatral como fundamento en La casa de Bernarda Alba, por lo que se propone, en estas líneas, una posible fuente cervantina en García Lorca que, hasta la fecha, siempre se había quedado fuera de las ya señaladas por la crítica.
\end{abstract}

Palabras Clave: Numancia; Cervantes; Alberti; García Lorca; tragedia; compromiso.

Title: Miguel de Cervantes' La destruición de Numancia: Rafael Alberti and Federico García Lorca have two alternative theatrical projects

\footnotetext{
Abstract

The readings that some writers of the Generation of 27 made about our classics have had a wide range of interpretations. Miguel de Cervantes was one of those authors resumed at the dawn of the Spanish Civil War and one of his works, La destruición de Numancia, was

* Universitat de València. sergio.arlandis@uv.es / ORCID iD: http://orcid.org/0000-0001-50314313 .
} 
soon considered as one of the ideological referents of the two sides. This work will focus on a specific discussion: to delve into the way in which two writers as Alberti and García Lorca, assimilated, so differently, the Cervantes' legacy, one bringing to the maximum its politicization the classic tragedy with its staging theatrical in Madrid; and the other - and this has not been studied yet- by how he tried to move away from that political core, remaining with the whole theatrical structure as a foundation in La casa de Bernarda Alba, so that a possible Cervantine influence is proposed in García Lorca who, to date, had always been left out of those already pointed out by critics.

Key Words: Numancia; Cervantes; Alberti; García Lorca; tragedy; commitment.

\section{Cómo citar este artículo / Citation}

Arlandis, Sergio (2017). «La destruición de Numancia de Miguel de Cervantes según Rafael Alberti y Federico García Lorca: dos propuestas teatrales alternativas», Anales Cervantinos. 49, pp. 169-204, doi: http://dx.doi.org/10.3989/anacervantinos.2017.008.

No hay estudio crítico, aportación, artículo, libro, monográfico de toda índole o pequeño apunte exegético si se quiere, que no se haga ya eco de ese manido recurso - porque este es el auténtico calificativo que merece- de señalar la inestimable e insalvable propensión del grupo poético del 27 por recuperar, utilizar (para acometer sus reivindicaciones estéticas) o recobrar de algún modo a los autores clásicos áureos; es decir, de señalar el camino de la tradición en el centro de la modernidad y de su impulso renovador vanguardista. Véase que se subraya aquí lo de poético pues, también con sorpresa, todo ha quedado reducido - en los estribos académicos - a ese ámbito o género, sin atender, en todo caso, hasta qué punto el teatro barroco, por ejemplo, influyó en la dramaturgia — casi imposible por ser fantasmas del papel como sugirió Max Aub- de esos experimentos literario-teatrales que muchos de estos escritores intentaron llevar a cabo incluso en su propia creación poética (Torres Nebrera 2009: 15). Porque los ecos y las influencias son limítrofes a ese riesgo feroz que implanta la originalidad: tan delgada es la línea que separa la copia de la influencia, lo epigonal de lo tradicional, y los parámetros que determinan su diferencia que no siempre están bien señalados, ni tampoco debidamente justificados pues ¿hasta qué punto un autor, clásico o contemporáneo, influye en otro? ¿y cómo se cuantifica dicha influencia? Se ha argumentado, con relativo acierto, que los puntos de inflexión que significan los homenajes o las efemérides, son, en verdad, reivindicaciones de una identidad propia que busca justificarse a sí misma, y para ello toma como punto de inicio lo que buenamente entendemos como clásico, una tradición, un aval canónico. Sobre esa recuperación de los autores áureos en el 27, Francisco Javier Díez de Revenga (2003), por ejemplo, ya ha efectuado un bien documentado estudio de algo que, realmente, no se puede cuantificar de ningún modo, siempre y cuando no se sobrepase el parámetro de la cita concreta o de la evidente e indiscutible necesidad de un autor por certificar un 
tributo determinado. Y cabría sumar — solo en estudios de visión panorámica como el de Díez de Revenga- los trabajos pioneros de Dámaso Alonso (1968), claro está, junto con los apuntes, esporádicos pero bien fundamentados, de C. B. Morris (1988), la aguda visión crítica (y editora) de Juan Manuel Rozas (1974) unido al amplio estudio general que dedicó Luis Rosales (reeditado en 1997) que reforzaba la antología preparada por el propio Rafael Alberti en 1933 titulada La poesía popular en la lírica española contemporánea, haciéndose eco de los más populares romances áureos; también podríamos añadir el completo volumen firmado por Aurora Egido (2009), el profundo análisis que llevó a cabo José Luis Calvo Carilla (1992) en torno a la presencia de Quevedo en estos poetas, o el de Raquel Asún (1986) más orientada a la concreta resonancia de Fray Luis de León. La lista, realmente, es amplia y muy variopinta, aunque nuestro propósito no es ni problematizarla ni revisarla, sino poner algunos referentes primeros que certifiquen que no se trata de un tema original en sí mismo y ni nuestro planteamiento va a arrojar diferente luz a nada de lo que ya se haya dicho en tantos estudios previos, salvo que la comparativa entre la visión y adaptación que hicieron Alberti y García Lorca sobre una concreta obra de Cervantes ${ }^{1}$, no solo sirve para señalarse alguna específica influencia (sobre todo en el caso de Lorca, pues Alberti realiza realmente una adaptación sui generis) ${ }^{2}$, sino en cómo se ha usado esa misma influencia cervantina, bien como modelo trágico secularizado (Stroud 1981: 303-307; Maestro 2004: 23), o como paradigma de una sociedad y de un período histórico concretos (es decir, politizándolo), o bien como renovación de una concreta visión del teatro clásico español, como trataron de hacer sendos poetas mediante sus respectivas propuestas dramáticas. Y esto entraba dentro de una intención renovadora que no distaba tampoco de lo que anteriormente intentaron hacer con otros autores (y otros géneros) como Luis de Góngora y el consabido homenaje en el Ateneo de Sevilla en ese mismo año que etiquetó al grupo al completo, a pesar de las

1. Como la cantidad de citas de los textos de los tres autores son abundantes, preferimos ir abreviando el modo de citarlas, así, para la edición de La casa de Bernarda Alba, que es la preparada por Allen Josephs y Juan Caballero en 1996 para la editorial Cátedra, lo haremos del siguiente modo: $L B A$ entre paréntesis, seguido del número de página; para Obras Completas, que consta de varias ediciones y volúmenes (aunque principalmente hemos usado el volumen segundo de la edición de la editorial Aguilar en 1980), lo indicaremos con $O C$, seguido el volumen y el número de página. Para las versiones de Rafael Alberti, publicadas conjuntamente en 1975 en la editorial Turner (y a ella nos remitiremos), pondremos $N A 1$ para la primera versión y $N A 2$ para la segunda, seguida del número de página correspondiente. Para las referencias al texto cervantino, entendemos que existen varias y muy interesantes ediciones, tanto la preparada por Alfredo Hermenegildo (1994) como la de Alfredo Baras (2009) o de Robert Marrast (1984) entre otras, pero hemos preferido referirnos al texto indicando solo el número del verso citado entre paréntesis.

2. Podríamos afirmar que con esta indicación de la influencia cervantina en algunos autores del 27 queríamos seguir ampliando ese camino abierto, entre otros, por Margarita Smerdou (1991) quien, sin embargo, dejó fuera de su escueta nómina a Alberti y García Lorca. De igual modo cabe resaltar el número monográfico de la revista Anthropos, publicado en 1989, donde también los dos poetas ya citados estaban ausentes entre los antologados por Ana Rodríguez Fischer. 
ausencias a tal acto $^{3}$, o con Lope de Vega y el bien estudiado III Centenario de su muerte en $1935^{4}$, o la sombra, siempre presente y alargada, de Fray Luis de León, San Juan de la Cruz, Francisco de Quevedo y del gran Calderón de la Barca, tan estimado, como sabemos, por los dos poetas andaluces, pero también por todo el grupo, como revelaba muy bien el excelente ensayo de José Bergamín, Calderón y cierra España y otros ensayos disparatados cuya versión final fue de 1979.

Cabe recordar, pues, que la primera inclinación de estos autores del 27 fue, como dijimos, la poesía de Góngora en esta tendencia esteticista y reivindicadora, que no dudó rápidamente en llamarse gongorina, a la que se le añadió de inmediato el prefijo «neo» con la intención de modernizar tal proceso de actualización: una emergencia de brotes barrocos muy metida en esa otra corriente que comenzó a aflorar en la España de la década de los treinta y que muy tempranamente también se calificó como neorromanticismo (Díaz Fernández 1985: 26) pero, sin embargo, estaba bastante alejada, aún, de la tendencia rehumanizada, también emergente por aquellos mismos años ${ }^{5}$ Una

3. Acertará el lector si amplía la búsqueda de información tomando como referencia el estudio de Gabriele Morelli (2001).

4. Como la bibliografía es extensa nos remitimos únicamente a algunos ejemplos de textos firmados por los dos poetas del 27 aquí trabajados: por ejemplo, conocemos la conferencia de Rafael Alberti, titulada «Lope de Vega y la poesía contemporánea española. (Influencia de Lope en Antonio Machado)», porque, además de conmemorar la figura del escritor áureo, confirmaba un nuevo giro en su propia trayectoria como poeta. Ahora bien: de aquella conferencia pocos son los datos que se conservan; incluso su original no se trataría exactamente de esa conferencia sino de la pronunciada, en ese mismo año y pocas fechas posteriores, en La Habana, el 5 de abril de 1935 según recogía la Revista Cubana (II, 4-5-6, pp. 68-93) y confirmará la edición llevada a cabo por Robert Marrast (1964) de su prosa. Aunque previamente ya había pronunciado la misma conferencia, con ligeras modificaciones (como la eliminación de Antonio Machado como objeto de estudio propiamente) en la Casa de las Españas de Nueva York, el 18 de marzo de ese mismo año, titulándolo esta vez: «La poesía contemporánea española». De dicha conferencia daba debida cuenta Revista Hispánica Moderna en su número 4 (año 1), julio de 1935, página 301, donde además se nos señala otra interesante conferencia, coincidente en el tiempo y en el espacio, pronunciada por Josefina Román, titulada «Lo popular en la lírica de Lope de Vega». Analizando las fechas, cabría preguntarse si la variación que realizó Alberti en el tema de su conferencia no tuvo la influencia del estudio de Román. Por otro lado, Federico García Lorca se sumó, sobre todo, con dos textos sobradamente comentados por la crítica y hoy recogidos en el volumen de sus Obras Completas (volumen II): "Lope de Vega en un teatro nacional», en 1934 y por motivo del estreno de la adaptación de La dama boba, y «La conmemoración del tricentenario de Lope de Vega», entrevista realizada por Nicolás González-Deleito ya en 1935. Queda clara, pues, la vinculación de los dos poetas andaluces con el acto conmemorativo de Lope de Vega.

5. Sobre este fenómeno del neogongorismo han dejado buenos y muy necesarios apuntes críticos autores como Elsa Dehennin (1962) o el volumen editado por Andrés Soria Olmedo (1997) o el citado Gabriele Morelli (2001) entre tantos otros muchos trabajos que han señalado su importancia desde aquellos primeros apuntes de Dámaso Alonso en 1927 y su paradigmático La lengua poética de Góngora, reeditado en su versión definitiva y ampliada en 1961. Sería lógico destacar los trabajos, comentarios, apuntes y demás conferencias que tanto Lorca como Alberti hicieron de Luis de Góngora, pero no es este el foro más apropiado y las lógicas limitaciones del espacio excusan que no caigamos en la acumulación de referencias ya conocidas por todo el mundo. Baste decir, en todo caso, que el hecho de traer al presente la figura de Góngora es que para los dos poetas andaluces su ingeniosidad metafórica sería reemplazada por la ingeniosidad conceptual de Cervantes. Este hecho vendría a poner sobre la mesa una evolución interna dentro del propio grupo del 27. 
veta estética que, a pesar de que algunos críticos señalaran como un auténtico fracaso en aquellas mismas fechas (Astrana Marín 1927: 18), marcó unos primeros pasos generacionales de los que, poco más tarde, trataron de desprenderse $o$ desentenderse ${ }^{6}$, aunque sin renegar de la poética gongorina abiertamente: por ejemplo, se determinó una suerte de equilibrio entre lo popular y lo culto, resuelto por los ritmos principalmente, por el duende, como diría en más de una ocasión del propio García Lorca, que, de algún modo, convertía sus herméticos textos en vasos comunicantes con un público más amplio.

Esa misma renovación del lenguaje dejó abiertas las posibilidades, en cambio, para que entrara un uso de la metáfora que se debatía entre la genialidad y el hermetismo, pues quedaba impregnada de cierta intuición, de un velado onirismo por donde el subconsciente (e incluso el humor) y el erotismo pasional e instintivo se dejaban entrever muy claramente tal y como ocurrió también en los entremeses de Cervantes (al menos para Lorca), ya que significó (o implicaba) un intento de liberación frente a la realidad opresora, como rebeldía trágica destinada al fracaso muy a menudo y como autenticidad frente a la civilización, con cierta predominancia de esa obsesión por el tema de la muerte y por los mitos, así como por las leyendas populares. Temas, como sabemos, especialmente sensibles en el Barroco. Pero esa síntesis o equilibrio entre la vanguardia y la tradición consistió también en la aceptación de los avances técnicos y estilísticos de la modernidad, aunque pasándolos por un filtro para adaptarlos a la obra personal de cada autor. Es decir, a fuerza de buscar ese pretendido equilibrio estos autores lograron superar esos ismos incorporando solo lo que les interesaba para dar cabida a la expresión de una nueva época, de los tiempos de cambio, pero también de los de decadencia, pues no olvidemos que, por ejemplo, no resulta casual que, tanto Alberti como Lorca, hicieran coincidir sus crisis personales con esta misma renovación interior. Frente a ello, resucitaron el interés, como dijimos, por los clásicos, especialmente Góngora, Gil Vicente y Lope de Vega, y de manera más velada, de Miguel de Cervantes (Arlandis 2016), así como por el romancero, que combinaron, con acierto, con el verso libre y del verso blanco.

Precisamente esa recuperación de lo barroco, a través de los iniciales cauces gongorinos (y que aquí estamos resumiendo sobremanera) les llevó a una estética que no quiso suprimir del todo (a pesar de los diagnósticos orteguianos) la anécdota ni el sentimiento, aunque fueron tratados de una manera antirrealista, individualizada y poderosamente simbolizada, buscando esencialidades, abstracciones o purezas primordiales de los instintos o de las pasiones. Esto nos lleva incluso a despejar la duda de por qué surge tanto interés por el auto sacramental entre estos autores, por ejemplo (Aragonés 1977: 58-62).

6. Son bien conocidas las manifestaciones que efectuó el propio García Lorca en una entrevista con Giménez Caballero en 1928 para aquel «Itinerarios jóvenes de España», donde decía: «Trabajar puramente. Vuelta a la inspiración. Inspiración, puro instinto, razón única del poeta. La poesía lógica me es insoportable. Ya está bien la lección de Góngora. Apasionado instintivamente, por ahora». (OC, II: 971). 
Pero más allá de esto, y de esa invisible línea que conectaba igualmente con la obra de Juan Ramón Jiménez, se buscó la expresión de emociones desde su construcción simbólica y simbolizada, pues se iba más allá de lo anecdótico, aunque partiendo propiamente de él. Y es ahí donde cabe apuntar un primer motivo del interés de Rafael Alberti y de Federico García Lorca por la obra de Miguel de Cervantes, La destruición de Numancia, bien porque representaba unos valores frente a un poder opresor, o bien porque la historia iba más allá de lo concreto y se dejaba anegar por la emoción, por la tensión humana, por sus temores, esperanzas, libertades, imperativos, frustraciones y deseos. Y esto igualmente iba más allá de la llamada rehumanización del arte, pues precisamente, como modelos de conducta, de respuesta humana, perdían esa condición de historias particulares para convertirse en abstracciones casi atemporales, quizá porque tanto Alberti como Lorca sabían — más el segundo que el primero - que la mejor manera de concretar una emoción era dotarla solo de perfiles, de trazos simbólicos para que el público, el lector o el oyente, les dieran su propio rostro, su veracidad como anécdota. Y en eso señalaron igualmente el magisterio, siempre constante, de Lope de Vega ${ }^{7}$ y más tarde el de Calderón de la Barca a quienes tanto Alberti como García Lorca dedicaron conferencias y bastantes elogios en entrevistas de todo tipo. Pero sobre todo partieron de la necesidad de despolitizar sus figuras para recuperar al poeta, al dramaturgo, al artista detrás de sus vitolas de clásicos hispánicos. Lo curioso es que, de algún modo, más tarde Alberti politizó la tragedia cervantina mientras que - fiel quizá a tal convicción- García Lorca la llevó al tiempo presente por encima de muchas de sus raigambres históricas, que sí tenía la obra de Cervantes. De hecho, el propio Lorca - y este pasaje es bien conocido - le reprochaba a Alberti esa politización de su obra un poco más tarde:

Igual en poesía que en teatro, que en todo... El artista debe ser única y exclusivamente eso: artista. Con dar todo lo que tenga dentro de sí como poeta, como pintor, ya hace bastante. Lo contrario es pervertir el arte. Ahí tienes el caso de Alberti, uno de nuestros mejores poetas jóvenes que, ahora, luego de su viaje a Rusia, ha vuelto comunista y ya no hace poesía aunque él lo crea sino mala literatura de periódico. ¿Qué es eso de artista, de arte, de teatro proletario! El artista y particularmente el poeta, es siempre anarquista en el mejor sentido de la palabra, sin que deba ser capaz de escuchar otra llamada que la que fluye dentro de sí mismo mediante tres fuertes voces: la $v o z$ de la muerte, con todos sus presagios; la voz del amor y la voz del arte (OC, II: 1002).

Quizá por ello Ricardo Doménech (1972: 103) dudaba de que realmente la generación del 27, en su conjunto, estuviera preparada para hacer un teatro

7. Si a la altura de 1615, en el prólogo a sus Ocho Comedias y ocho entremeses, el propio Cervantes se tuvo que rendir a la evidencia de la superioridad de la fórmula teatral lopesca ¿cómo no lo iban a hacer estos autores contemporáneos? 
que hiciera frente a las exigencias de la contienda histórico-estética del momento, con todo su aparato de presión institucional: el teatro político. Y quizá también este mismo rechazo, manifestado por Lorca, hacia el teatro político (que no equivale a la etiqueta de comprometido) fuera uno de los motivos por los que Javier Huerta Calvo (2016: 2) llegara a afirmar, atendiendo a la alta textura politizada de la tragedia cervantina, que a Lorca no le parecieron interesar ni las comedias de cautiverio, ni la Numancia, porque el granadino veía al dramaturgo auténtico en los entremeses ${ }^{8}$. El excesivo apego del texto cervantino a la política de su tiempo (esa desgarrada defensa de la corona de los Augsburgo en su eclosión expansiva) posiblemente mermara la explícita devoción de García Lorca a esta concreta tragedia, pero no por ello derivó en rechazo, sino que necesariamente debía transformarse para alcanzar la esencia de lo teatral que en sus versos latía. Alberti, en cambio, sí vio en la tragedia un perfecto modelo de lucha ideológica (más la primera versión que la segunda) que adaptó para sí sin pudor alguno, también tratando de «recuperar para la causa republicana a muchos autores del siglo de oro» tal vez por su naturaleza popular e incluso revolucionaria (Baras 2014: 263). De hecho, para Patricia McDermott (1993: 254-255), y a juzgar por su repercusión mediática, puede considerarse este como el más relevante evento teatral de la República.

La recuperación de Cervantes (que podría ser tomado como el perfecto ejemplo de equilibrio entre clasicismo y modernidad) llevada a cabo por estos escritores no solo atendía a una reivindicación de lo español: fueron reclamados como emblemas o banderas de actitudes ideológicas, muchas de ellas tomadas como simples pretextos y muy alejadas de la autenticidad de los textos. Y esto resultó más visible en el teatro frente a otros géneros. El propio José Díaz Fernández ya dio buena cuenta, en El nuevo romanticismo (1930), cuando exigía un auténtico teatro para el pueblo (y no sabemos hasta qué punto esto entraba dentro de las pretensiones dramáticas de García Lorca y La Barraca, por ejemplo), que pusiera en «comunicación con esa democracia ávida y estremecida como un amanecer. Hacer teatro de vanguardia para minorías es tan estéril como escribir en el agua» (Díaz Fernández 1985: 141). ¿Pero qué teatro para el pueblo y sobre qué elementos (temática, ideología, autores) representados? Cierto es que ni la II República, ni la guerra después, a pesar de ser coyunturas históricas supuestamente favorables, lograron imponer la renovación de la escena española (Monleón 1992: 378-379; Aznar Soler 1997). La razón se encontraba, en primera instancia, en la persistencia

8. Esta parece una opinión generalizada entre la crítica: por ejemplo, Jesús G. Maestro (2013: 53) no valora su influencia directa en la dramaturgia de García Lorca, pero sí ve, con gran nitidez, la influencia cervantina en La zapatera prodigiosa o en Amor de Don Perlimplín, como ya antes lo había visto Joaquín Forradillas en 1978 en la edición crítica de la primera. Una línea de opinión que continuó Jean Canavaggio (1983). Mucho más próxima a nuestra lectura es la aguda valoración de Edwin Honig (1964), quien estableció paralelismos entre el desciframiento y la codificación de la realidad entre los dos autores, encontrando, con ello, coincidencias interesantes tras el paño de su lenguaje y mundo simbólicos. 
de la cultura teatral del país, dicha así como un reclamo general y generacional. De igual modo lo reconocía Luis Cernuda desde las páginas de El Mono Azul, durante la propia contienda, cuando afirmaba: «La guerra, que tantas cosas ha removido, y que directamente ha podido ser origen de una total desaparición de esas obras teatrales embrutecedoras del público, no parece aportar hasta ahora una rectificación» (Cernuda 2002: 131-136). Embrutecimiento que se asoció a la España nacional, conservadora y castiza. Ahora bien, también el teatro impulsado por la II República escondía, tras su reivindicación de un teatro tradicional, un programa ideológico, frente a la dramatización de su propia crisis que tanto caracterizó a la burguesía europea de aquellos años. En consecuencia, el teatro fue evasivo porque la burguesía española tuvo temor a los cambios: por ejemplo, en 1936 en la revista Leviatán, Sender denunciaba la función evasiva de la comedia burguesa, pues distraía y desviaba «la atención del público de aquello a lo que naturalmente se inclina. ¿Y cuáles son los problemas hacia los que se orienta la atención de la grande y la pequeña burguesía? Hacia la inquietud social, la amenaza del paro obrero, la quiebra de los viejos valores morales» (apud Dougherty y Lima 1984: 115). Porque en la España de los años veinte y treinta cabría hablar, pues, del teatro como instrumento político, tal y como se ha hecho para los años que transcurrieron entre 1895 (fecha del estreno de Juan José de Joaquín Dicenta) y 1914, cuando tomó nuevo impulso esa conciencia liberal que desembocaría finalmente en la II República. No en balde, Dougherty y Lima (1984: 145) llamaron la atención sobre la significativa coincidencia de que el mismo «impulso liberal» que fomentaba la reforma escénica contribuyera al nacimiento del nuevo régimen político. Pero en realidad era una cuestión que convendría situar más atrás, en la España de la Restauración y del desastre de fin de siglo. La crisis del teatro desde finales del siglo XIX fue, como señaló Serge Salaün (1996), un concepto complejo que iba más allá del terreno meramente artístico y estético porque resultaba indisociable de los intereses ideológicos de las burguesías que dominaban el panorama cultural español desde 1875 en adelante, porque, en verdad, «el teatro se debe imponer al público y no el público al teatro» (García Lorca 1997: 256). Y frente a esa desazón del cambio imposible se iba a reabrir una ruta que vieron como segura: la relectura (es decir, la revisión de su puesta en escena desde el principal elemento del lenguaje) de los clásicos españoles, aquellos que llevaron la escena española a la cima de su ingenio siendo capaces de satisfacer a un público tan heterogéneo en lo económico, en lo social y en lo cultural, aunque algo más homogéneo en su concepto del espectáculo teatral. Todo, pues, entraba dentro de una casuística histórica donde forzosamente modernidad y tradición debían convivir y complementarse.

Cervantes sería, sin duda, la apuesta de las élites minoritarias frente a la reivindicación de Lope de Vega, precisamente porque en los períodos de crisis surge la renovadora voz de una estética disidente que anuncia, desde su ruptura, esa desintegración de los valores que la sustentan. Por tanto, es ahí donde cabría encuadrar la obra teatral de Cervantes (o su rescate) y no como 
resorte comparativo frente al exitoso espectáculo teatral lopesco, «teatro para un público extemporáneo» a fin de cuentas (Maestro 2003: 20-21). Cervantes representaría, mejor que nadie de entre sus coetáneos, ese calificativo de moderno, justamente en los umbrales del decisivo cambio del pensamiento humano (antropocentrismo, desarrollo científico, racionalismo). Tal trayecto crítico propuesto nos acaba llevando hasta la orilla de un principio fundamental que, en líneas generales, es lo que intentaron llevar a cabo muchos de estos autores del 27, porque «leer a Cervantes desde el cervantismo, endogámicamente, no nos permitirá fácilmente ver nada nuevo más allá del cervantismo» (Maestro 2003: 28). A partir de ahí surgió un interés por mostrar un Cervantes «precursor del mundo contemporáneo, liberal, ilustrado y laico» (Maestro 2003: 28). Dar forma, en definitiva, a una lectura plural, ensanchadora, exhaustiva de aquellos factores que hicieron de la obra de Cervantes un emblema cultural, estético e ideológico puramente atemporal. En consecuencia, lo rescatado del autor áureo no solo fue una idiosincrasia a la española que había que purgar con una proyección exegética ética y antropológica hacia adentro, como proponía Ortega y Gasset en Meditaciones del Quijote (1914): se pretendía rescatar esta vez de Cervantes su capacidad de profundizar en una conciencia perforada por la permanente sensación de insatisfacción que, de algún modo, calificaba degenerativamente a la sociedad española y esto, a su vez, enlazaba con los instintos asaltantes bretonianos que se expresaban, por ejemplo, en El retablo de las maravillas ${ }^{9}$. Pero no solo eso: universalizar a Cervantes era, paradójicamente, hacerlo más propio, más español, como concepto en sí; y es ahí donde, tanto el repentino giro afectivo hacia la obra de Lope de Vega, como el abierto reconocimiento de Cervantes iban a encontrar, en los autores del 27, unos animadores y seguidores casi incondicionales. Y esto, a su vez, se unía a esos otros grandes proyectos culturales y literarios que fueron, entre otros, La Barraca de Federico García Lorca, el Teatro de Arte de Gregorio Martínez Sierra, el grupo El Búho promovido por Max Aub, o el Teatro de la Escuela Nueva de Rivas Cherif con ciertos impulsos de renovación de la escena teatral de la década de los treinta en España.

Pero preguntémonos en qué medida la obra teatral cervantina influyó en la obra de Federico García Lorca, La casa de Bernarda Alba, por un lado; y por qué Alberti tomó el texto cervantino como gran metáfora de la España ocupada y asediada por el franquismo: no en vano la de Lorca fue escrita en 1936 y estrenada en 1945, mientras que la segunda tuvo su primera edición en 1937 en la editorial Signo y una segunda en 1943 en la bonaerense editorial Losada, que, a su vez, en 1946 también publicara, de la mano de Guiller-

9. Quizá ha sido Jean Canavaggio (1983) quien más atención ha dedicado a la unión entre los entremeses cervantinos y los lorquianos y a su extraordinario trabajo, así como al de Marta Castillo (2008) al que remitimos por su especial interés. En todo caso, sirva el siguiente dato: en una colección de naturaleza divulgativa, orientada principalmente para los más jóvenes lectores, en la editorial Castalia (serie «Prima») podemos encontrar una curiosa edición conjunta titulada Dos retablos y un retablillo, publicada en 1999, con la doble autoría Cervantes-Lorca y donde se recogen El retablo de las maravillas y El retablo del Maese Pedro, del primero y El retablillo de San Cristóbal del segundo. 
mo de Torre, la primera edición de la obra lorquiana. Los datos al respecto están sobradamente reseñados en muchos de los estudios que, individualmente, se han encargado de las dos obras, pero cabe tener presente la relativa coincidencia en las fechas y su azaroso juego de cifras y ediciones.

En dos ediciones críticas de estimable valor, tanto Alfredo Hermenegildo como Alfredo Baras inciden en el gran valor teatral de La destruición de Numancia, pues sobrepasa los hechos históricos, «al no ser más que un sistema de referencias que el dramaturgo va a remodelar según sus particulares intereses» (Hermenegildo 1994: 11). Incluso Zimic ya calificó — previa matización de Casalduero (1966: 27), de Valbuena Prat (1979: 21) y de Marrast (1957a: 19) - que esta obra, con argumento patriótico pero con aspiración de otra índole más profunda y universal, se trataba no solo de la «obra maestra entre las comedias cervantinas, sino también como una de las piezas más notables del Siglo de Oro y hasta la tragedia nacional por antonomasia», pues su lectura ha dejado «honda impresión en algunos de los espíritus más egregios del mundo, de orientación filosófica muy distinta y, por supuesto, de exquisitos criterios intelectuales y artísticos» (Zimic 1992: 57-58). Una repercusión que, con todo tipo de detalles, estudiaron posteriormente Francisco Vivar (2004) y Frederick A. de Armas (1974) por ejemplo. Muy claramente lo vio el dramaturgo Max Aub, quien había reseñado la puesta en escena llevada a cabo en París en fechas anteriores realmente a la propuesta albertiana, en $1937^{10}$, y afirmaba:

La supervivencia de la Numancia se debe, ante todo, a su excelencia como obra dramática. Pese al canto a la grandeza española que encierra si careciera de virtudes dramáticas no se hubiese puesto en escena ni en Zaragoza en 1808, ni en Madrid años más tarde, por Maíquez, ni hubiese suscitado el entusiasmo que mereció la refundición de Rafael Alberti, en Madrid, en 1937, ni se hubiese llevado a escena, el mismo año en París, por la compañía de Jean Louis Barrault. Ni la hubiese vuelto a representar Margarita Xirgu en Montevideo, en $1943^{11}$; ni andaría reimpresa —en una u otra versión- en las colecciones más populares.

La Numancia, tras un primer acto de noble exposición, ve crecer el interés en los tres actos siguientes, sin que falte nunca movimiento ni pasiones

10. En concreto, se estrenó el 22 de abril en el Teatro Antoine, bajo la dirección de Jean Louis Barrault, decorados de André Reosson, con la ayuda de la Junta Delegada de Relaciones Culturales. Más tarde el propio Aub editaría, sin especial novedad, El Cerco de Numancia en México en 1965. A raíz de esta puesta en escena parisina (que el propio Alberti trató de poner por detrás cronológicamente de la suya primera en Madrid) parece muy probable, según los estudios de M. ${ }^{a}$ de los Ángeles González Briz (2007) y Alfredo Baras (2014), que fue Max Aub quien convenció a Alberti de llevar a los escenarios españoles la obra cervantina. Esta adaptación francesa ha sido ampliamente estudiada por Jean Canavaggio (2004), Robert Marrast (1957b) y Francisco Torres Monreal (1994).

11. Véase la extraordinaria coincidencia entre nombres y fechas en el interés por la obra de Cervantes, y la publicación de La casa de Bernarda Alba y de la adaptación de Alberti. Precisamente Margarita Xirgu llevó a los escenarios tanto la versión primera de la obra lorquiana como las adaptaciones de Alberti. Además, la actriz, así como Max Aub también, acudieron como espectadores en el estreno de la adaptación del propio Alberti en Madrid. 
humanas en los tipos episódicos que no desamparan en ningún momento la escena. Añádese, inmortal, el canto desesperado del sacrificio colectivo en pro de una idea. Podrá faltar una estructura central interna, tal vez sobre los personajes episódicos, pero la idea que mueve a Cervantes es la que le da vida. Quiso su autor exponer la grandeza española ante la adversidad y la muerte, y ese empuje es el que moverá la admiración de extraños antes que la de propios. En eso la Numancia pertenece claramente al teatro de su época: no se encierra en sus peripecias, al contrario: la voluntad del autor es visible en todo momento y en muchos de ellos tiene que recurrir a figuras alegóricas para hacerlas patentes (que las haya introducido por vez primera en el teatro Miguel de Cervantes, tal como asegura, es problema que carece de importancia como no sea para fechar la obra) (Aub 1956: 110-111).

Cervantes, a través de su tragedia, se hacía eco de una estructura profunda, de un modelo teatral muy concreto (y que es nuestro objetivo de análisis y de comparación): un pueblo militarmente poderoso (pongamos el eco, por ejemplo, en la conquista de Germania) conquista o intenta conquistar a la fuerza a un pueblo inferior en recursos militares ${ }^{12}$. Pero saquemos esta vez, de nuestras líneas, el eco patriótico que realmente ${ }^{13}$ Cervantes quiso darle a su $\mathrm{Nu}$ mancia teatral para poder ahondar en otros aspectos de su obra. Si bien, no podemos olvidar que escribió La Numancia poco después de la anexión de Portugal a la Monarquía española, entre 1581 y 1585, dentro también de un

12. Atendamos a un dato que no resulta irrelevante: ¿acaso Cervantes planteaba que España (la postrera nación surgida del sacrificio numantino) era inferior en coraje, en medios o en valentía con respecto a sus enemigos? ¿Cómo podía plantear algo así en una época donde curiosamente era la corona española la invasora? Durante el siglo XVI y motivado por la situación política derivada de las campañas militares llevadas a cabo por los Habsburgo, los humanistas europeos comenzaron a articular la idea de la barbarie cultural en la que estaba sumida España motivada, según ellos, por los siglos de guerras y herencia cultural árabe. Se alzaron entonces numerosas voces contrarias a estas visiones del pasado español, sobre todo de las italianas (y luego, como sabemos las flamencas, francesas e inglesas con la famosa Leyenda negra) tratando de defenderse de todas aquellas acusaciones y contraatacando con diferentes argumentos, tales como la sublimación de los valores castellanos (recordemos los emblemas que llevara el personaje España en esta obra de Cervantes: «Coronada con unas torres y trae un castillo en la mano, que significa España», según versa en la acotación colocada entre los versos 352 y 353), elogiando igualmente el papel jugado por los Reyes Católicos al restituir la unidad de España y las gestas militares protagonizadas desde la antigüedad. Y esto hizo que también los humanistas españoles se tuvieran que debatir entre la admiración por el clasicismo grecorromano, al verlo como modelo a imitar, o por la exaltación de un «pasado» español en el que sus protagonistas se habían visto obligados a enfrentarse a las pretensiones de dominio romano. Y es que, en España, desde mucho antes, ya se achacaba a ciertas desgracias sobrevenidas a la presencia de «naciones extranjeras», de ahí que la sucesión de los cartagineses por los romanos no fue sino una simple continuación de aquella tiránica explotación. La desviación, entonces, del original cervantino en la versión de Alberti resultaría más que evidente, ya que la imagen del opresor militar tomaría mayor fuerza en la versión contemporánea indiscutiblemente, quizá porque sus propios objetivos ideológicos eran también distintos.

13. Con esto no queremos negar, como hizo Vicente Gaos, ese trasfondo militarista que, sin embargo, muchos críticos sí han visto en la obra cervantina. Recordemos que Gaos afirmaba: «A mi ver, no hay nada de eso. Cervantes nunca fue «imperialista», no era Lope, ni tuvo por ideal, como Acuña, un imperio, un monarca y una espada. La Numancia no es imperialista, ni bélica, sino pacifista» (Gaos 1989: 134). Por desgracia, el historial biográfico de Cervantes no invita a pensar así. 
determinante período en el que se restauró el antiguo territorio español (la reintegratio Hispanae que se había expresado tantas veces de un modo apocalíptico) alzando la figura de Felipe II a la de gran pastor y monarca. Pero tal unificación, a lo largo de la historia, siempre fue acompañada de un declive interno. Ahora bien, en la obra cervantina se enfrentan el Imperio Romano contra el limitado pueblo numantino, pero al incorporar las figuras alegóricas (Guerra, Enfermedad, Hambre, La Fama, Duero, España) unía ese hecho pasado con el presente para ensalzar la monarquía española y el imperio universal de Felipe II, heredero de ese pasado purgado, eso sí: es decir, la profecía nos llevaba al futuro, pero manteniendo siempre una profunda relación con el pasado. Porque el origen numantino anticipaba el reino que habría de venir con Felipe II, con lo que Cervantes presentaba así la caída de un imperio (el romano) y el nacimiento de un nuevo imperio universal, de estirpe española, a través del sacrificio (suicidio) del joven Bariato, y que nacía de las cenizas del pueblo numantino y esto lo expresaba en el propio texto cuando afirmaba en su parlamento final a cargo de La Fama:

Indicio ha dado esta no vista hazaña del valor que en los siglos venideros tendrán los hijos de la fuerte España, hijos de tales padres herederos (vv. 2433-2436).

Por lo que, en Cervantes, realmente, este pasaje histórico se convertía en esperanzado ${ }^{14}$, donde se podían distinguir dos períodos: un antes y un después, uno de sombra y otro de luz, y donde se puede entender el destino de España por el pasado numantino y las acciones de los propios numantinos por el futuro de España (Tuveson 1949: 4-5) ${ }^{15}$.

14. Un final esperanzado que entraría abiertamente en conflicto con el primer final de las dos versiones de Alberti (y que bien le costó una buena sarta de críticas por su derrotismo, sobre todo en la primera de ellas) y con ese final, agónico, de La casa de Bernarda Alba con aquel «Nos hundiremos todas en un mar de luto» ( $L B A$ : 199), donde curiosamente se hace hincapié en la joven edad del sacrificado por la causa trágica: «Ella, la hija menor de Bernarda Alba, ha muerto virgen» (LBA: 199). Véase que en todo caso ese mismo final colectiviza igualmente la tragedia, así que lo sigue aproximando, nuevamente, a otro aspecto identificativo del texto cervantino.

15. Cervantes se sirvió de la trágica epopeya para justificar la responsabilidad histórica contraída por los castellanos, y por ende España y la dinastía de los Austria, para guiar los destinos de la humanidad: sobre todo debería de estar justificando aquel Saco de Roma de 1527, tomado como una deuda póstuma que se cobró España en nombre de Numancia, estableciendo, como dijimos, una conexión entre pasado y presente y una expiación, si se quiere, de los pecados. Así que es la historia, revisada teatralmente, hecha tragedia cuyo final no sabemos muy bien si es triste o feliz según el prisma que empleemos, como ocurrirá más tarde también con La tempestad de Shakespeare. Numancia aparece convertida en un mito de resistencia y de amor a la libertad, pero también es empleada como un recurso emocional que permitirá reafirmar la unidad de España y establecer una relación con el pasado. En consecuencia, será para unos una tragedia, como en el ejemplar que se conserva en la Hispanic Society of America; para otros, como data en el manuscrito de 1600 que se conserva en la Biblioteca Nacional, una comedia. Tal es la ambivalencia de esta obra y la posibilidad que ofrece, como estudió atentamente Paul Lewis-Smith (1987). 
Pero aún más: ese Bariato en descenso era realmente una ascensión, que hacía ir de la vida a la muerte, pero también del olvido a la memoria, frente a otro modelo pagano - el romano- que iba en sentido inverso, de la ascensión a la caída y por tanto, al olvido. Es a Bariato (que es símbolo de la hispanidad venidera) a quien le espera la vida inmortal, la católica, en verdad. Pero la religión en Cervantes necesitaría una profundidad crítica que aquí no podemos mostrar adecuadamente. Nos interesa más indicar que lo que realmente sale reforzado de este sacrificio (y este suicidio no puede justificarse de otro modo en la mentalidad católica) es un final de lo trágico a manos de la historia y del surgimiento de la política, abriendo unos horizontes muy diferentes (y muy modernos) a la idea de libertad personal y colectiva. Porque recordemos parte de la motivación cervantina: Felipe II, que por entonces estaba articulando desde Badajoz toda una estrategia política para acceder al trono lusitano, quizá aprendiendo de viejos actos que, si bien estaban justificados (lo vimos) ya no daban la horma a los nuevos tiempos. Se dice que es la política quien sustituye a la tragedia, de ahí que Napoleón le dijera a Goethe aquello de que las tragedias pertenecían al pasado, a una época más sombría, ya que le preguntaba aquello de ¿qué tenemos que ver nosotros hoy con el destino? Y es que la acción política limita la idea del destino impuesto, pues se trata de un plan diseñado por el hombre para el hombre, que puede fracasar o tener éxito. Así, lo trágico como colectividad, es ya una cuestión del pasado y solo lo individual, que es el resultado de cada libertad personal, puede estar sujeta a la tragicidad o ananké. Ahora bien, como ya afirmó Jesús G. Maestro (2013: 71): «La estética cervantina nos muestra cómo la modernidad toma conciencia de lo que habría de ser para el futuro la interpretación de la experiencia trágica: el reconocimiento de la crueldad del hombre contra sí mismo»; una crueldad que la política debía - y suena a pura utopía - contrarrestar.

No hay oráculo posible en la política, porque la negociación siempre está abierta a condicionantes de todo tipo. Y en la obra de Cervantes constatamos que toda negociación fracasa, como en el texto de García Lorca, de ahí que la obstinación nos lleve al fracaso, al sufrimiento, a la purgación: fracasan los emisarios numantinos que piden la tregua en la primera Jornada; también fracasan los intentos, también numantinos, de cerrar la contienda con una guerra entre iguales al comienzo de la tercera Jornada; y tampoco tendrá éxito Cipión con Bariato al final de la cuarta y última Jornada. No hay negociación que triunfe, porque no hay política de fondo: solo deseos no consumados y que buscan aplacarse acorde con la naturaleza y el instinto de cada cual. Y en García Lorca tampoco bastarán las advertencias a Adela, tanto de la abuela María Josefa, como de La Poncia y de sus hermanas. Porque lo realmente dramático, parece decirnos Cervantes, es que no podemos imaginar ninguna sociedad en la que lo trágico esté ausente y eso nos lleva a la piedad y al terror, como las escenas, tan manoseadas por la crítica por su impacto, de la madre con sus dos hijos hambrientos y a punto de desfallecer, o la de Lira con Merandro, muerto en sus brazos. Así que si la obra de Cervantes es 
moderna podría ser porque en verdad solo la memoria de nuestros actos puede salvarnos de un final sumido en el olvido, en la fatalidad.

Lo cierto es que la tragedia contemporánea pone ese daimón dentro de nosotros mismos, con su imposición como determinación personal, lo que nos convierte en víctimas de nuestra libertad, de ahí lo paradójico del proceso y su ridiculización posterior. De ahí igualmente que García Lorca pudiera sentirse atraído por el conflicto más esencial de la obra cervantina: ya lo decía Yerma, por ejemplo, en la celebrada tragedia lorquiana de mismo título, cuando su oráculo interior le anunciaba su sequedad y muerte interna en el turbio futuro de su matrimonio, es decir, la fatalidad de su obstinación. Y es que la necesidad, que mueve a la acción, arranca de lo hondo, como a Merandro le impulsa ir en busca de comida para Lira, o a Leonicio, asentado fuertemente sobre el importante valor de la amistad, le lleva a acompañarle a tal suicida aventura. La acción, pues, se sitúa tanto dentro como fuera del héroe, así que la causa está también en su naturaleza, y eso es lo que debe regir la política, que restringe las libertades de cada cual siempre un busca de una armonización colectiva pues ¿qué hubiera sido de Numancia si Bariato no hubiera decidido libremente lanzarse al vacío y pensar solo en sí mismo? La muerte no hubiera sido trágica, sino innecesaria y, por tanto, ridiculizada. Alberti lo mostró como un acto de dignidad y García Lorca como un gesto de rebeldía, pero en los dos casos siempre fue visto como un paso necesario ante la imposición de una ley existencial injusta y opresora, que daba la espalda a la política. Por tanto, lo trágico estribaba en esa libertad de acción, no en su determinación. Eso nos legó Cervantes, que miraba su sacrificio como un paso más en esa rueda imparable que era la expansión española. Seguramente, con los años y tras el rechazo (o silencio) de las atenciones monárquicas, hicieran ver con más escepticismo toda aquella utopía política que parecía despuntar en los albores del siglo XVI.

Con insistencia, Jesús G. Maestro, que tanta y tan buena atención ha dedicado a esta obra cervantina, ha asegurado que la utopía real radicaba en aquella Numancia irreal que históricamente nunca existió, con aquellos consejos abiertos a la pluralidad, incluso de la opinión femenina que es, a la postre, la que les llevó realmente a la grandeza del presente. De este modo nos dice que la modernidad de Cervantes se dio porque finalmente abogaba «trágicamente por la utopía y el precio de la utopía es la tragedia» (Maestro 2004: 46); es decir, la libertad numantina cuya amenaza nunca fue justificada podría unirse a la idea de libertad que más tarde subyacería en El Quijote. Ahora bien, pensemos que no es una sociedad utópica la que está en jaque, sino un modelo que, curiosamente, no se salva sino que debe sacrificarse para la auténtica grandeza del país. Claro, esta lectura se hace viendo el uso (o la renovación) que se le dio a la propia tragedia ya desde el siglo XIX con la invasión francesa y el sitio de Zaragoza ${ }^{16}$, o con la

16. No obstante, con total probabilidad, Alfredo Baras tenga toda la razón al afirmar que se trataría realmente de la versión adaptada de Ignacio López de Ayala, Numancia destruida, impresa en 
amenaza franquista y fascista italiana como hizo en este caso Rafael Alberti por partida doble.

Es el debate entre el destino y el libre albedrío lo que plantea igualmente Cervantes en esta obra y que nos dirige de nuevo hacia la atenta lectura lorquiana: un debate que, en todo caso, queda matizado y condicionado por aquello que José Ortega y Gasset llamó la «circunstancia» concreta de sus apuntes biográficos. Y es ahí donde el texto cervantino se muestra más laxo en su interpretación y donde las dos versiones contemporáneas (aunque hay muchísimas más, claro está) de Alberti y Lorca, se construyen.

La realidad histórica, sin embargo, es que tras largas jornadas de asedio (lo que llevó a muchos al suicidio), los supervivientes entregaron la ciudad, que fue reducida a cenizas por los romanos y el territorio distribuido entre las tribus aliadas y aledañas al pueblo romano. De los rendidos, algunos fueron vendidos como esclavos y unos cincuenta llevados a Roma como trofeo para la marcha triunfal de Escipión. El mito, convenientemente, olvida todo lo que obstaculiza la formación de un icono nacional que da testimonio de unidad y continuidad con la historia patria. Omite que los numantinos eran celtíberos y paganos, y por tanto a duras penas precursores o precedentes del nacionalcatolicismo; que coexistían con otras tribus celtíberas en la península y que no dudaron en aliarse con el invasor ${ }^{17}$; o que sobre las cenizas de Numancia se construiría un enclave romano, símbolo quizá de lo inútil de su sacrificio. Ninguno de estos detalles es reflejado en la lectura politizada de los dramas, como es lógico, siempre y cuando se haga patria de los mismos; aunque, en verdad, fue el mismo Cervantes el primero en desmentir la naturaleza de documento histórico de su tragedia al apuntar a su carácter ritualizador cuando admitió, en el famoso prólogo de 1615 a una parte de su teatro, que en esta obra se había atrevido a representar «las imaginaciones y los pensamientos escondidos del alma, sacando figuras morales al teatro» (Cervantes 2005: 92). No puede extrañarnos, por tanto, que a raíz de esta misma lectura de Cervantes, Joaquín Casalduero se quejara de que las producciones teatrales de la tragedia numantina, en los siglos XIX y XX «deformaran» el original (Casalduero 1966: 28), imponiéndole contextos políticos concretos o que, también, Francisco Sánchez Castañer, se lamentara, a la altura de 1976, de la

1775 y estrenada en 1778, frente a la de Cervantes, que fue publicada algo más tarde por primera vez por Antonio Sancha en 1784. El éxito, en cambio, de la versión de López de Ayala fue mayor que el de Cervantes si juzgamos su impacto a partir de las reediciones y el número también de representaciones, muy superior en el primero de los casos (Baras 2014: 249). Léase también, en esta línea, el excepcional estudio monográfico de Alfredo Jimeno y José Ignacio De la Torre (2005), además del trabajo ya conocido de Francisco Vivar (2004).

17. El texto de Cervantes tiene algunos puntos sobre los que a veces una lectura parcial y mediatizada ha pasado por alto sin rubor alguno. Sin duda, este sería uno de ellos, sin despreciar lo más mínimo la naturaleza un tanto mercenaria de algunos españoles, de ahí que en el texto leamos versos como los siguientes, en boca de Teógenes, al comienzo de la segunda jornada: «No sólo a vencernos se despiertan / los que habemos vencido veces tantas, / que también españoles se conciertan / con ellos a [s] esgar nuestras gargantas. / Tan gran maldad los cielos no consientan. / Con rayos hieran las ligeras plantas / que se muestren en daño del amigo / favoreciendo al pérfido enemigo» (vv. 545-552). 
proliferación en el siglo XX de tantas versiones «políticas» de la obra cervantina (Sánchez Castañer 1976: 17).

Cierto es que la historia del pueblo (o individuo) cercado que prefiere el honor de la auto-inmolación a la derrota constituye un drama ceremonial por excelencia y necesita por ello de un público receptivo a sentimientos patrióticos o al menos reivindicativos. Estas son precisamente las condiciones que han causado que el mito numantino reapareciera en aquellos delicados momentos en que la idea de la nación se veía amenazada o en proceso de redefinición, de ahí que Numancia quedara ya como «símbolo político universal de libertad» (Baras 2014: 250; Vivar 2004: 35).

Y esta autodeterminación apunta necesariamente al problema del destino como eje y a las aristas del deseo y del albedrío como pilares fundamentales de las posteriores versiones contemporáneas de un mismo tema: el domingo 26 de diciembre de 1937 en el Teatro de la Zarzuela de Madrid, promovido por el Teatro de Arte y Propaganda, dirigido por María Teresa León, se estrenó (o así estaba proyectado) la primera versión que se conoce del texto de Cervantes hecha por Alberti. Dicha puesta en escena volvió a repetirse el día $27^{18}$. Con tono casi épico, Marcelino Jiménez León (2001: 1181) recoge el testimonio de María Teresa León en su Memoria de la melancolía, donde son evocados los bombardeos de la aviación resonando en la techumbre del viejo teatro y el heroísmo de un público identificado con la tragedia, viviéndola en esa primera persona de una España amenazada en su libertad. Como anécdota, El Sol del día 28 reseñó la presencia de autoridades civiles y militares (generales Miaja y Cardenal, coronel Matallana, director general de Bellas Artes, José Renau, teniente de alcalde Escanilla) entre el pueblo llano o los milicianos llegados del frente, haciéndose eco de este tono épico, combativo, de resistencia de un pueblo ante el empuje de un poder alienante en este caso. Pero la obra tardó medio año en ser vista regularmente en el escenario una vez fue concluida entre el 10 y el 17 de junio. Bajo el epígrafe «La Numancia de Cervantes» se anunciaba su inminente estreno ya «para el 18 de julio» en

18. Alfredo Baras (2014: 243-244) añade información muy precisa al respecto: representaron la obra actores del Teatro Escuela de Arte, cuya labor fue calificada de excelente sin reparos por la prensa republicana: se nombra a Luis Peña padre (Escipión) e hijo, Edmundo Barbero (Morandro), Juan M. Benítez, José Franco, Santiago Rivera, Salvador Arias (Leoncio); y a Carmen Jiménez, Juana Cáceres, Julia Delgado Caro, Carmen Ontiveros, Mercedes Servet, Dolores Villaespesa, Rosario Coscollá (bailarina) y la niña Maribel. Actuaron, a su vez, los Coros del Orfeón Confederal. Santiago Ontañón se ocupó de la escenografía y del vestuario y Jesús García Leoz de la música. Efectivamente, y tal y como recoge Baras, tanto César Oliva (2003: 258) como Gregorio Torres Nebrera (1982: 45) dan esta fecha del preestreno, pero Ricardo Doménech (1972: 97) y Marrast (2003: 248) se refieren al día 27, y McDermott (1993: 254-255), así como Mateos y Santonja (apud Alberti 2003: 706), en cambio, al 28. Los diarios $A B C$ (7) y El Sol (2) del 28 y 29 de diciembre respectivamente anuncian esos días el estreno. El segundo ofrece el día 28 una reseña del ensayo general (1-2); deja la crítica «para mañana, en que daremos cuenta del estreno»: en efecto, el 29 se publica el texto de Eduardo de Ontañón, titulado «Cervantes en nuestra trinchera. El primer teatro digno de nuestra guerra» en $E l$ Sol. Tanto por esto como por el noticiario El Liberal del 27, que anuncia el estreno ese día en la sección de «Espectáculos» (6), ha de datarse entonces para esa fecha y no el 28. Tal vez el problema resida en que el lunes 27 no salieron la mayor parte de los periódicos. 
El Mono azul $(19,1)$ - primer aniversario del golpe de estado curiosamente-- pero se retrasó hasta diciembre acaso por coincidir con el II Congreso de Escritores Antifascistas (Jiménez León 2001: 1180-1181). La representación volvió a anunciarse otras tres veces en la misma revista: el 25 de noviembre, para «la primera decena de diciembre» $(42,1)$; el 2 de diciembre, según el propio Alberti, dentro «de una decena de días» $(43,1)$; y el 9 de diciembre, la «próxima semana» $(44,1)$.

No cabe duda de que esta versión logró un gran éxito popular y económico $^{19}$ : se mantendría en cartel hasta el 8 de marzo de 1938 (Marrast 2003: 249), casi dos meses y medio. Su éxito fue innegable y hasta Eladio Mateos y Gonzalo Santonja contabilizaron unas setenta representaciones (apud Alberti 2003: 706), suponiendo que se llevó a cabo una diaria, de forma ininterrumpida, entre la primera fecha y la última; pero esto no está probado y hay un error al datar el estreno el 28 de diciembre y no el 26. Y no solo eso: al pie del Prólogo de Alberti se puede leer: «Madrid, 7 de noviembre de 1937», mientras que la última página indica: «Esta obra acabose de imprimir el día 5 de noviembre de 1937» (Jiménez León 2001: 1197); supone el crítico - como documenta Baras (2014) - el posible deseo de hacer coincidir el prólogo con el primer aniversario de la defensa de Madrid. Bajo el epígrafe «En breve» anunciaba El Mono Azul del día 4: «Numancia de Cervantes. Adaptación y versión actualizada de Rafael Alberti (Editorial Signo)»; pero había algo más que celebrar: abría el mismo número de la revista un artículo de Salas Viu titulado «7 de noviembre. XX aniversario de la Revolución de Octubre. Un año de la heroica defensa de Madrid» $(44,1)$.

En cuanto al libro, encabezado por el nombre de Miguel de Cervantes ante el título de Numancia. Tragedia en tres jornadas. Adaptación y versión actualizada de Rafael Alberti (Signo, Madrid, 1937), y del que se conserva un ejemplar en la Biblioteca Nacional de España y otro en la Biblioteca del Instituto del Teatro de Barcelona, se acabó de imprimir el 5 o el 7 de noviembre, casi dos meses antes de ponerse en escena la tragedia, y en coincidencia con el vigésimo aniversario, como dijimos, de la Revolución de Octubre (McDermott 1993: 255). Igualmente en noviembre la revista Acero reproducía el artículo del autor «Numancia, ejemplo de resistencia y heroísmo». Y el 2 de diciembre El Mono Azul recogía otro breve ensayo con el título «Numancia, tragedia de Miguel de Cervantes» ${ }^{20}$. Este artículo es muy similar al pró-

19. La propia María Teresa León recordaba el precio exacto de la entrada que, a juzgar por el número de representaciones, sería más que válido para rentabilizar la obra: diez céntimos (Baras 2014: 243).

20. Para un estudio en profundidad de los dos artículos en su comparativa y el desarrollo de la hipótesis de que los dos los hubiera escrito el propio Alberti, véase el imprescindible trabajo de Alfredo Baras (2014). Igual caso ocurrió con los dos artículos publicados por María Teresa León en 1942, titulado «La tierra arrasada» en España Democrática en Montevideo, y por Rafael Alberti, titulado «Comentario a la Numancia», conferencia del 17 de septiembre en Buenos Aires, publicado más tarde también en España Democrática en 1947. Véase el estudio de González Briz (2007) para más detalles sobre estos dos artículos. 
logo de la edición de 1937 y su contenido acaso coincidiera con el de las cuartillas leídas por Alberti desde el escenario, tal y como el propio poeta relató en La arboleda perdida I, aunque muy soslayadamente, así que no sería descartable que fuera el propio poeta andaluz quien lo escribiera, aunque ocultando su nombre. Parece lógico sostener que la adaptación «estuvo acompañada por un aparato propagandístico nada desdeñable» (Jiménez León 2001: 1180). Y esto fue así porque «Alberti transforma el original de Cervantes en una auténtica obra de propaganda, o si se prefiere, de urgencia» (Hermans 1989: 174). Porque, en verdad, esta adaptación albertiana veía de este modo el problema del asedio del poderoso, la humana voluntad, corrompida por el poder intransigente encarnado en el fascismo alienante (aunque en la segunda versión esto se mitigara y transformara), como enemigo cerrado de lo democrático, de lo dialéctico, de las libertades esenciales humanas: esa fue la versión que pretendía dar de la tragedia cervantina, sin lugar a dudas quizá movido también por el éxito previo que la obra tuvo en Francia y que tan minuciosamente estudió Jean Canavaggio (2004).

Una segunda versión — la segunda Numancia de Alberti- fue llevada a las tablas por Margarita Xirgu el 6 de agosto de 1943 en Montevideo. Para entonces ya era muy diverso el contexto histórico: lo inmediato de la contienda había sido sustituido por la perspectiva que aportaban cuatro años de un régimen cuyo fin no se veía próximo y por tanto, debía dar respuesta a otro panorama regresivo (Hermenegildo 1993: 61). E incluso no faltaban voces que identifican a ese poder asediante con la mano ejecutora del franquismo, del mismo modo, aunque de manera sumamente disparatada y anacrónica, se veía en Bernarda Alba la visión apocalíptica del régimen nacional. Los dos textos de 1937 y 1943 volverían a ser editados en 1975, año también emblemático para la historia contemporánea española, con gran número de variantes respecto a los originales. Y como curiosidad, ninguna edición numera los versos, pues existen variantes importantes con respecto al original cervantino, como es lógico. Y es que en la versión de Alberti, Escipión (o Cipión) pierde toda su aura mítica y su fuerza noble y se convierte en un personaje de instinto primitivo, imagen de la opresión, de la disciplina como estrangulamiento de la libertad humana y no vemos que en ese sentido difiera tanto de lo que representa Bernarda Alba como imposición de un modelo ideológico social, generador de conductas sociales en la época: ya no es, como bien apunta Hermenegildo (1994: 27-28), un modelo de conducta militar, un ejemplo de nobleza (que, de algún modo, dignifica la batalla) ${ }^{21}$, sino un tirano, un general al que no le tiembla la mano a la hora de ejecutar la más cruel de las

21. Curiosamente uno de los significados, de estirpe germana, del nombre de Adela, que es la víctima mortal del texto lorquiano, es «nobleza» (calificativo que siempre se da al pueblo numantino, por otro lado) aunque también, en griego, significa «lo no manifestado y por tanto, lo invisible». En los dos casos podemos establecer una directa correspondencia con el texto cervantino también en este sentido, pues ese será el destino también del obstinado general Escipión: el anonimato de su hazaña, de su victoria. 
sentencias: la muerte de los inocentes en beneficio de su fin, con esa renovación del planteamiento de Maquiavelo en El príncipe (Vivar 2004: 84-86). Porque el Cipión cervantino (que siempre se presenta, eso sí, altanero y soberbio) sí muestra justicia hacia los numantinos: en la versión de Alberti se suprimen algunos versos que muestran ese lado más honorable del general romano; pero si así no fuera, nos hubiéramos encontrado, en el caso cervantino, ante un personaje dominado por la pasión del poder en el que destacaría la característica de la soberbia, como dijimos. Por ello, no acepta ni el vasallaje ni la amistad que le proponen los numantinos, y es así como, en verdad, este héroe romano se convierte, realmente, en el gran derrotado de la obra, pues la Fama será (y así acaba la obra) para los que realmente vencieron a pesar de encontrar la muerte, ya que nadie recordará el nombre del victorioso general romano y sí, en cambio, esa colectividad, muy al margen de lo que podría ser la de Fuente Ovejuna o la de Zalamea, por ejemplo, conocida por su gentilicio. Por eso, en el momento de ver el fuego de Numancia, dice el propio general romano: «sin duda alguna que recelo y temo / que el bárbaro furor del enemigo / contra su propio pecho no se vuelva» (vv. 2188-2189), fragmento que Alberti, por otro lado, apenas modificó. Y es ahí donde el general romano reconoce parte de su error en la estrategia y ve que el camino del abuso de la fuerza solo le ha llevado a la destrucción. Alberti, que tantas variaciones introdujo en el texto y así lo admite, sin pudor, en la nota introductoria de las dos ediciones (luego recogidas, como dijimos, en 1975), mantiene esa soberbia del general, pero no reclama para él una posible catarsis: sabe que el movimiento ofuscado (harmatia) de su ejecución militar quiere seguir el plan de un designio puramente humano, que obedece al capricho del poder y por tal instinto destructivo se ha guiado: quedará la Historia como la gran ejecutora y justiciera de esa acción, pues le espera el mismo silencio que el general ve, de inmediato, en las murallas de una $\mathrm{Nu}$ mancia que ha elegido libremente resistir a un destino o liberarlo más allá de su predicción, lo cual convierte este hecho en trágico. Las sutilezas con las que Alberti deja entrever esta visión del Cipión como derrotado no dista en exceso de las del texto de Cervantes, solo que en este último el romano admite que los numantinos han sido «memorables en su hazaña» (v. 2401) y que esto marcará la identidad española para siempre y forjará una esencia, una personalidad, por eso «Tú con esta caída levantaste / tu fama y mis victorias derribaste» (vv. 2407-2408) y Alberti, en cambio, no solo mantiene esta parlamento, sino que además añade (y son muchos los ejemplos en este sentido) ${ }^{22}$, otro parlamento, en boca de España, en la edición de 1943, que afirma:

22. Sobre las diferencias entre las dos ediciones no podemos apuntar con excesiva extensión todas y cada una de ellas: remitimos, de nuevo, al magnífico estudio de Alfredo Baras (2014) para que el lector pueda extraer todas las apreciaciones que considere oportunas, entendiendo que este trabajo tiene como principal objetivo señalar solo algunos puntos de conexión y variación, principalmente en torno a la figura del opresor, como modelo estructurante y simbólico. No obstante, se ha indicado que existe una mayor perfección en el segundo texto, más fiel a Cervantes y sin las alusiones urgentes de la guerra (Hermans 1989: 180-181; Hermenegildo 1993: 62-63). Como señala Jiménez 
Nadie toque este niño que ha apagado la sola luz que en esta hoguera ardía, volviendo en polvo y viento arrebatado cuanto el feroz romano pretendía. Tú no serás mi último soldado, niño valiente de la sangre mía, mientras pueda vivir para ofrecerte los nuevos vengadores de tu muerte. Yo te prometo, $; \mathrm{Oh}$ pueblo de pastores! Ya en silencio mortal desvanecido, que verás tus funestos vencedores cual hoy te ves en humo convertido.

¡Alzad, sombras queridas, los clamores! ¡Vuelva el aliento al corazón perdido! cante la Fama, y en su libro impresa deje esta verde espiga mi promesa! (NA2: 146).

Ciertamente, en la voluntad de Alberti (que atiende también a la voluntad de recuperar esta obra cervantina) estaba la de enlazar su versión con la también representada en Madrid, cuando parece ser que el actor liberal Maíquez era vitoreado por el público y reprendido por las autoridades -recordemos las alusiones de Aub- en el instante que recitaba aquellos pasajes relativos a la libertad en plena época absolutista. Por ello se refería Alberti, con especial interés, al pasaje de Cervantes en que las mujeres numantinas hacían desistir a sus maridos del propósito de salir a morir esa noche en una acometida, donde se hallaba un octosílabo $(7+1$ concretamente) por él respetado: «¡Numantinos, libertad!» (v. 1357), que más tarde se haría bandera del republicanismo en defensa del derecho del pueblo español. Por esto, no nos extraña que Jiménez León (2001: 1179) se preguntara «qué llevó a Alberti a realizar una adaptación de la Tragedia de Numancia». Mientras que él mismo daba un comienzo de respuesta anotando aquella puesta en escena francesa de $1937^{23}$ y el tremendo interés parisino (¿acaso no pasó lo mismo, por ejem-

León, las principales divergencias las encontrábamos en la doble extensión del prólogo, dividido en tres partes y sin la exaltación de otro tiempo. La didascalia inicial es también más extensa e incluye precisiones sobre la puesta en escena, luz y oscuridad, y orquesta: la Obertura del Coriolano de Beethoven, sustituida al cabo «de seis a siete minutos» por otra música «más alegre»; se sustituye la breve escena inicial de 1937 por otra extensa, separándola de la Jornada Primera: Macus aparece disfrazado de Cleónice y Buco de Lisístrata, heroínas de la comedia de Aristófanes: la segunda hace jurar a Cleónice que no cederá a las demandas amorosas de su marido hasta que este olvide la guerra. Y sin caretas, bailan, luego, enlazados. En la Jornada I aparecen como embajadores Corabino (personaje distinto en Cervantes) y Numantino 1, «ancianos de largas barbas y sayales blancos, cubierta la cabeza por una piel de lobo»; y en la Jornada III España aparece «con manto verde y un haz de espigas en la mano» acompañando a la Fama. Por lo demás, siguen presentes la reducción y la distribución de las tiradas largas entre varios personajes, así como las omisiones mitológicas o religiosas. Hay cambios sustanciales en las acotaciones y en los parlamentos, pero sobre todo en los finales de la primera y la tercera jornadas. Frente al desenlace esperanzador de 1937, ahora España «cierra el libro de la Historia y se hace el oscuro» (Jiménez León 2001: 1190-1192).

23. Sin duda se refiere a la versión libre, ya citada líneas atrás, de un joven Jean-Louis Barrault de veintiséis años, estrenada en el teatro Antoine de París, donde al texto se superponía «une inter- 
plo, con las canciones de Paco Ibáñez algunos años más tarde?) por esta obra cuyo éxito (hasta 18 pases en dos meses) traspasó lo puramente teatral y se convirtió en testimonio vivo de una opresión al pueblo español que se consumía en una guerra inútil (pero inevitable según se veía) así que esta tragedia superaba los límites estrictos del género, como lo haría, más claramente, Federico García Lorca, en La casa de Bernarda Alba.

En el mes de marzo de 1945, y en el Teatro Avenida de Buenos Aires, Margarita Xirgu y su Compañía Escuela, con la concurrencia escenográfica de Santiago Ontañón ${ }^{24}$, estrenaban la última obra teatral de García Lorca, fechada el mes de junio de 1936 y que ya fue publicado en el último volumen de las Obras Completas del poeta granadino en la editorial Losada igualmente en el señero año de 1937. A España la obra llegó el 22 de marzo de 1950 por primera vez a los escenarios a cargo del Teatro del Ensayo «La Carátula», bajo la dirección de José Gordón y José María de Quinto ${ }^{25}$. En aquella ocasión Xirgu se rodeó de un reparto en el que figuraban actrices de su máxima confianza como Teresa León, María Gámez o Isabelita Pradas, compañeras que ya habían compartido escena con la maestra catalana en el mes de junio del año anterior, cuando en el mismo teatro la actriz retornaba a los escenarios precisamente con una obra de Rafael Alberti, El Adefesio, donde también se relataba un encerramiento (el de Altea en este caso) muy parejo al de Adela en el texto lorquiano, con una curiosa similitud vocálica entre los nombres. Sobre la recepción de este estreno resulta altamente aconsejable, por su valor documental, el excelente trabajo de Nel Diago (2012: 147-169), aunque nosotros no nos detengamos en este aspecto. Ni tampoco en las coyunturas editoriales (que fueron muchas) del propio libro, aunque sí podemos remitirnos a cualquiera de las ediciones críticas que circulan, siendo la preparada por Allen Josephs y Juan Caballero (1996), bajo nuestro criterio, la que más soluciones aporta en torno a sus claves internas.

No podemos pasar por alto que García Lorca ya hizo una adaptación, un tanto libre, de una obra clásica con tintes políticos, o mejor aún, con tintura politizada: Fuente Ovejuna de Lope de Vega ${ }^{26}$ en marzo y abril de 1934 . Y

prétation très espécial de l"eactuelle guerre d"Espagne» (Pitollet 1937: 406), según cierta reseña de Stefan Priacel en el diario L'Humanité fechada el 4 de mayo. Pitollet, que da la fecha del 24 de abril - sin identificarla con el estreno-, afirmaba en Post-Scriptum haber enviado su propia nota con la crítica de Barrault antes del 8 de mayo (Baras 2014: 252).

24. Curiosamente el propio Santiago Ontañón se encargó de la escenografía en la primera puesta en escena de la adaptación de Alberti en Madrid, en 1937.

25. Aunque tradicionalmente se afirmaba que su primera puesta en escena en territorio español fue el montaje que dirigió el cineasta Juan Antonio Bardem en el teatro Goya de Madrid el 10 de enero de 1964.

26. La admiración de García Lorca por Lope de Vega es amplia y está muy bien documentada. Basta, en todo caso, traer al presente una explícita referencia de Ian Gibson para constatar el aprecio del poeta granadino al respecto: «Por esa época, Lorca y el grupo de la Resi solían frecuentar el restaurante Los Gabrieles, cerca del Ateneo, donde sus modales y atuendo nunca dejaban de atraer la atención de los otros clientes del establecimiento. Un día, mientras comen en un reservado del local, Federico exclama: «iA Lope de Vega quien le continúa soy yo, y no Juan Ramón Jiménez!» Aquella frase, que provoca una ruidosa discusión, se le clavó en la memoria a una de los presentes» (Gibson 
los resultados, a juzgar por las palabras del propio poeta, no fueron del todo satisfactorios $^{27}$ (Huerta 1995: 480-482) quizá también porque resultaba demasiado evidente su carga político-ideológica o su manipulación para tal causa, por encima de su estructura dramática ${ }^{28}$. Quizá también porque fue usado como obra reivindicativa republicana sin que el autor quisiera hacer acopio de ello $^{29}$. No extrañe entonces que, poco más tarde de esta puesta en escena, llevada a cabo por La Barraca, se propusiera llevar nuevamente a Lope de Vega al escenario ${ }^{30}$, aunque en este caso sería la comedia La dama boba, y tras ella seguirían las siguientes afirmaciones que, al observarlas con una perspectiva más general, podrían darnos algunas claves de la intención posterior de García Lorca con el texto de Cervantes: a la altura de 1934 ya decía

1987: 381). Y más gráfico es el testimonio de Pepín Bello, gran amigo del poeta granadino, quien decía: «Al influjo de Lope nació un rito en la Residencia que tenía Federico como sacerdote: metido en la cama, se respaldaba en dos almohadas superpuestas, cogía la obra de Lope que había seleccionado y recitaba» (Martín Otín 2008: 93). Para seguir ahondando las influencias de Lope de Vega en la obra lorquiana véanse los recientes trabajos de David Rodríguez-Solás (2016) y Andrés Soria Olmedo (2016).

27. Tal vez esta insatisfacción lorquiana fuera el motivo por el que Santos Martínez Sáura (1998) no le dedicara ni una sola línea en su estudio sobre su supuesta obra política. No obstante, Martínez Sáura (1998: 177) sí afirma que la obra de Lorca rechazó realmente a la «España reaccionaria» y eso afectaba o incluía a los dos bandos. Ahora bien, hay que recordar aquel pasaje del 12 de julio, cuando García Lorca hizo, supuestamente (y aquí hay al menos hasta tres versiones y fechas distintas) la última lectura íntima del manuscrito de La casa de Bernarda Alba, cuando tras sus palabras muchos de los asistentes comenzaron una acalorada discusión política, con clara alusiones a la figura de Alberti y sus derroteros comunistas de nuevo cuño por aquel entonces y cómo García Lorca, con nervios, dijo aquello de — según Ian Gibson (1998: 650-654) — «Ya no voy a hacer nada... ¡Y Yo nunca seré político. Yo soy revolucionario, porque no hay verdaderos poetas que no son revolucionarios ¿No lo crees tú así? Pero político ¡No lo seré nunca!». Para una explicación más detallada, véase el citado trabajo de Ian Gibson (1998) o el también interesante de Hilario Jiménez Gómez (2003).

28. No podemos más que hacernos eco de las contundentes palabras que hizo Edwin Honig (1974: 197) sobre el compromiso lorquiano, aunque también, como toda cita descontextualizada, requeriría una profundización mayor por nuestra parte que aclarara lo que el crítico quería afirmar con ello: «Lorca hace de sus dramas un acto de crítica social además de presentar en ellos el documento de un conflicto personal no resuelto». Como ignoramos la base de dicho conflicto personal no resuelto solo podemos atender a que, ciertamente, el teatro lorquiano traspira cierto aire reivindicativo, aunque también lo es el hecho de que toda iniciativa comprometida, de impulso vital y personal, acaba en fracaso, en soledad, en locura o en muerte ¿el fin de la utopía? Tal vez, pero las estructuras no se alteran a pesar del fatal desenlace, ni hay una respuesta motivada por el impacto social de lo visto/ representado. Sinceramente pensamos que se trataba más de un modelo empático dramático que de una defensa aferrada a su compromiso social, que también lo tuvo, claro que sí.

29. Que hubo una lectura en clave de esta obra lo pone de manifiesto que, unido a la Numancia albertiana, Juan Chabás, el 2 de septiembre de 1937 en El Mono azul (número 31), alababa esta vez la validez de la tragedia cervantina en cuestión y ensalzaba, también, la puesta en escena de Fuente Ovejuna (a pesar de juzgar como liviano el compromiso de La Barraca) como ejemplo de la «expresión del heroísmo colectivo, popular» (Chabás 1937: 1). No olvidemos que la Falange criticó duramente esta propuesta teatral de García Lorca, a la que calificó de «derroche de libertinaje» (Wahnón 1995: 412). Por tanto, parece claro que cada bando político-ideológico veía en los clásicos españoles un arma o un escudo de intereses muy poco estético-literarios.

30. No olvidemos que también llevó a los escenarios, entre agosto de 1935 y abril de 1936, El Caballero de Olmedo y que tuvo que modificar su final al que vio como posible objeto de manipulación ideológica (Sánchez García 2012: 209). 
«la refundición, es decir, la tarea de suprimir escenas y partes enteras, sería muy fácil, pero es un sacrilegio [...] Quede, no solo lo esencial, sino lo mejor de ella [...] también más perfecta, porque ahora queda de ella lo más grande, lo más justo, lo más armonioso, lo más bello» (OC, II: 1054). ¿Y si trató de hacer lo mismo con la tragedia cervantina sin caer en el populismo reaccionario del que siempre quiso huir? No es descartable, desde luego. Tampoco es descartable que el poeta granadino quisiera deshacerse de la sombra de politización que ya se cernía, en 1936, sobre él y su obra así como de su elección de llevar ciertas obras y autores clásicos a los escenarios, por lo que tomaría la estructura dramática de los mismos, purgándolos de todo su mensaje ideológico, es decir, hasta dejarlos en pura estructura. Por ello, coincidimos, pues, con Ricardo Doménech cuando afirmaba que Lorca ofrecía «innumerables pruebas de su lectura inteligente, fecunda, de Cervantes, Lope, Calderón, etc. En primer lugar, a través de la praxis escénica [...] no como una influencia superficial, sino como una asimilación estilística y conceptual, profunda» (Doménech 2008: 27).

Porque parece que aún estaban muy patentes aquellas tempranas manifestaciones, en 1932, donde el propio Lorca hacía explícito aquel proyecto de educar al público (aleccionamiento de estirpe tan cervantina) a lo nuevo, desde el remedo clásico, de tal modo - dirá el propio poeta- «por el teatro de Cervantes se llega [a] la farsa más esquemática [...] y se llega al gran drama» (OC, IV: 395-396). Entonces, ¿no es lo esquemático de La destruición de Numancia lo que adopta y adapta Lorca al tiempo presente, al nuevo camino del teatro español? Lo cervantino en la esencia de lo popular o mejor aún, en lo esencial de lo popular. De ahí, igualmente, que al hablar de Bodas de sangre, afirmase en 1933 que, al principio, estaba «impresionado por el tema, olvidé el suceso, y la obra poética fue tomando forma en su ser» (OC, II: 1009) ${ }^{31}$. Análoga a la intención de Cervantes, quien del suceso numantino saltó a otras formas, con la entrada de las figuras alegóricas o morales, que proyectaran la Historia de lo anecdótico a lo nacional. Curiosamente, esa entrada de lo alegórico-poético (tan criticado en Cervantes) era, para García Lorca, rasgo consustancial de su propio teatro. Véase, en este sentido, que el propio poeta granadino afirmaba - con su enigmática obra La destrucción de Sodoma de fondo ${ }^{32}$ — que «el realismo que preside hasta ese instante la tra-

31. De esto mismo se dio cuenta Antonio Machado cuando en Hora de España (n. ${ }^{\circ}$ 8, agosto de 1937: 11 y 15) su teatro había llegado al pueblo, al «alma popular» que era donde quedaba depositado lo «esencial humano», así que la obra lorquiana se emparentaba a la de Shakespeare, Tolstoi y - cómo no- Cervantes. Sobre esta idea nos parece sumamente acertada la lectura llevada a cabo por Marta Castillo al señalar a Lorca como el «defensor de la tradición, según el nuevo concepto reivindicado por los escritores republicanos en las páginas de Hora de España, y de contenido radicalmente diferente al que se daba a este término en el bando contrario. De ningún modo se trataba de olvidar, de borrar, toda la tradición cultural del pasado, sino de hacer desaparecer las interpretaciones que la ideología contraria había legitimado del proceso histórico español» (Castillo 2008: 488).

32. El hecho de que Lorca titulara una supuesta obra suya como La destrucción de Sodoma no puede pasársenos por alto dentro de esas conexiones que estamos trazando en el presente trabajo. El propio García Lorca afirmó en 1935 que esta misma obra, que no podemos asegurar que se trate de 
gedia en quiebra y desaparece para dar paso a la fantasía poética, donde es natural que yo me encuentre como el pez en el agua» (OC, II: 996); frente a lo cual Cervantes volvía a ser el auténtico referente: «[Cervantes tiene] la facultad de ir guiando los asuntos por un cauce previsto sin que jamás falte el temblor misterioso de lo inspirado. Alameda plateada con estilo personal donde el poeta permite que entre un viento de no se sabe dónde» como afirmó en 1933 ante los alumnos de la Universidad Popular de la Federación Universitaria Escolar (apud Huerta Calvo 2016: 6) ${ }^{33}$. Y esto enlazaba con esa aspiración de García Lorca, comparándose con los grandes autores teatrales de todos los tiempos, afirmando que «el teatro que ha perdurado siempre es el de los poetas [...]. No es — claro- el poeta lírico, sino el poeta dramático»

La casa de Bernarda Alba, vendría a cerrar una trilogía que comenzó con Bodas de sangre y continuó con Yerma. Resulta difícil no establecer una rápida correspondencia entre La destrucción de Sodoma y La casa ... sobre todo porque de la primera dijo que trazaba una «línea trágica de nuestra vida social: las españolas que se quedaban solteras. El drama empieza en mil ochocientos noventa, sigue en mil novecientos y acaba en mil novecientos diez» (OC, II: 1078). Unos veinte años que, curiosamente, coincide con la edad de Adela. A raíz de tales afirmaciones desconocemos por qué Doménech llegó a afirmar que «en ningún momento dice que esta venga a cerrar [La destrucción...] el ciclo trágico de Bodas de sangre y Yerma; antes bien, sus comentarios [...] tienden a señalar distancias, diferencias con respecto a todo el teatro que había escrito hasta entonces» (Doménech 2008: 163). Quizá la afirmación se debiera a que solo se apoyó en la declaración que realizó Lorca en El Heraldo de Madrid, a José S. Serna, en 1933, donde exponía: «La tercera está madurando ahora dentro de mi corazón. Se titulará La destrucción de Sodoma» (OC, II: 999) sin hacer conexión alguna con el resto de obras. Y tampoco puede pasarnos desapercibido el hecho de que García Lorca hizo algo semejante con La vida es sueño de Calderón, que llevó a los escenarios con La Barraca, así, en plena vorágine creativa, anunciaba otra obra de la que nada sabemos, titulada El sueño de la vida. ¿Quizá quiso hacer lo mismo con la obra de Cervantes, alterando su título pero manteniendo sustancialmente el eco del modelo clásico?

33. Claro está, estas palabras nos conectan con la famosa teoría del duende lorquiano y que no podemos atender con profundidad. Baste en todo caso traer al presente algunas manifestaciones del poeta al respecto y que, nuevamente, vuelve a tomar a Cervantes como modelo: decía Lorca a Alberto F. Rivas en 1933 que «el ángel ondula sobre la frente, guía y regala; la musa dicta y en algunas ocasiones sopla. Pero estas cosas vienen del exterior; en cambio, el duende, ¡ah! El duende, amigos, está en uno, en la sangre, en el alma. Muchas personalidades han escrito cosas soberbias pero no siempre han tenido duende. Cervantes tuvo un duende gigante, pero con tanta serenidad, que aparecía a la consideración popular exactamente como si no lo hubiera tenido nunca», porque el duende - hay que recordarlo - era «ese misterio magnífico que debe buscarse en la última habitación de la sangre» (OC, II: 1032). Y no olvidemos la tan citada conferencia, titulada Teoría y juego del duende, donde se nos dan, bajo la teoría del duende, unas buenas claves en torno a la propia obra La casa de Bernarda Alba. Así, tras la curiosa y azarosa citación del ejemplo de Felipe II, muy casualmente coincidente como ejemplo en la tragedia cervantina, afirma: «Parece como si todo el duende del mundo clásico se agolpara en esta fiesta perfecta, exponente de la cultura y de la gran sensibilidad de un pueblo que descubre en el hombre sus mejores iras, sus mejores bilis y su mejor llanto. Ni en el baile español ni en los toros se divierte nadie; el duende se encarga de hacer sufrir por medio del drama, sobre formas vivas, y prepara las escaleras para una evasión de la realidad que circunda»; si bien, líneas antes (y haciendo nosotros algunas conexiones obligadas con la tragedia lorquiana aquí comentada) ya había afirmado que «el duende no llega si no ve posibilidad de muerte, si no sabe que ha de rondar su casa, si no tiene seguridad de que ha de mecer esas ramas que todos llevamos y que no tienen, que no tendrán consuelo», para acabar — el autor granadino - con aquel «Duende de Quevedo y duende de Cervantes [...] coronan el retablo del duende de España» (García Lorca 1980b: $185-186,184$ y 188). 
en 1935, ya que «no puede haber teatro sin ambiente poético, sin invención» (OC, II: 1087).

Para buena parte de la crítica el núcleo temático de La casa de Bernarda Alba planteaba el sometimiento del instinto natural femenino a las rígidas normas de la moral y las convenciones dentro de una sociedad que, en materia sexual y personal, negaba a las mujeres todo lo que le permitía a los hombres. Esa norma estricta que señalaba a la mujer como «solterona» y que resonaba en la copla musical a través de la voz de Concha Piquer y su célebre «A la lima y al limón», por ejemplo, parecía un poderoso yugo, como una ley no escrita pero sí seguida, que ataba a la mujer al casamiento como opción de esa liberación de la sexualidad que era tanto como la propia libertad (paradójicamente) social ${ }^{34}$. Esa misma represión tendría, como sabemos, consecuencias trágicas, pues el deseo sexual aparecía (y de ahí también sus vestigios de surrealismo velado) como una fuerza elemental derrotada irremisiblemente por unos poderes superiores, arbitrarios e irracionales llevados, de manera recurrente en el mundo lorquiano hasta la figura simbolizada de la luna. Como en el caso de Cervantes, poco importaba — pensamos - si esto estaba fundamentado en un hecho concreto de eso que Unamuno calificó como la «intrahistoria» nacional: la barrera social estaba muy por encima de lo anecdótico, y García Lorca, también aspiraba (y acaso Alberti en esto se desmarcó al querer vincular tan directamente su adaptación numantina al asedio militar de Madrid en un primer momento) a un valor más universal (en lo que atañe a la mujer) y nacional (en lo que a su representatividad se refiere) la frustración del deseo como destino fatal del género humano, cuya única solución es la muerte, entendiendo que el ser humano solo tiene la libertad de vivir o de no hacerlo. Porque Lorca, a través de la muerte de Adela, expresaba el fracaso de esa tiranía del hombre, de los valores patriarcales que se anquilosaban en otros valores vistos como caducos por él mismo, tales como el honor y la honra (Azcue 2002: 117-118). Como en Cervantes también, esa muerte de Adela, la oprimida, es en verdad la derrota de Pepe el Romano (a pesar de que, como se afirma, «salió corriendo en su jaca» [LBA: 198]), como lo será para Escipión ese suicidio colectivo del pueblo numantino, de ahí que diga Bernarda, en tono amenazante: «Pepe, tú irás vivo por lo oscuro de las alamedas, pero otro día caerás» ( $L B A: 199)$. No lo es para Bernarda, que ya estaba condenada al silencio de la casa y a la resignación, pues Adela no se quita la vida por miedo a su madre, sino por el amor imposible de Pepe el Romano al que creerá muerto por los disparos: nuevamente un engaño (lo hace el pueblo numantino igualmente) y la muerte como resultado, como ese destino ineludible que acaba con la conciencia personal y los dimensiona como modelos trágicos para la colectividad. Por tanto, esta obra, que ya hemos

34. Las referencias a esa fuerza poderosa (cuya interpretación y lectura son sumamente plurales) aparecen de manera insistente a lo largo de toda la obra lorquiana: recordemos el tenso pasaje entre Adela y La Poncia, en el segundo acto, por ejemplo, o entre la propia Adela y Martirio casi al final de la obra. 
puesto en comparación con la cervantina, representa muy claramente la lucha y la derrota de la vida fecunda contra la muerte inútil, de la libertad contra la tiranía, de lo natural y elemental contra lo convencional.

Pero este eje principal no puede oscurecer temáticamente una obra tan prolífera en contenidos de todo tipo: queda clara la injusticia de una educación sexista, basada en los valores tradicionales que condenan a las mujeres a la pasividad (el luto, la casa) y en una moral de la decencia, del silencio, como dijimos, de ahí que se afirmen cosas como «Nacer mujer es el mayor castigo» ( $L B A: 154)$, o «nos pudrimos por el qué dirán» (LBA: 137). Y esto mismo Cervantes también lo había denunciado ya en su tragedia, pero las mujeres cervantinas tienen voz y la usan decisivamente para determinar el buen tino de la hazaña, que les llevará a ser reconocidas heroicamente en el futuro. En cambio, las mujeres lorquianas solo tendrán silencio y olvido, pues nadie juzgará su sacrificio benévolamente y aquí es justo reconocer, otra vez, que el significado de Adela, en griego, es la invisible, la que no se manifiesta.

Y más allá de esto, también encontramos ese exagerado (y atemporal) sentido de la honra y la reputación, unido al exacerbado orgullo de pertenecer a una casta superior, aunque ello conlleve al aislamiento (como hace Bernarda) y la falta de libertad por la obligación de someterse a esas normas de las convenciones sociales: un incongruente sentido patrio, de identidad propia y orgullo (obstinación), que lleva a la condena de uno mismo, al camino del odio, que es, en verdad, lo que se desprende de estas palabras de Bernarda a La Poncia: «No hay en cien leguas a la redonda quien se pueda acercar a ellas. Los hombres de aquí no son de su clase. ¿Es que quieres que las entregue a cualquier gañán?»( $L B A: 134)$; o le recrimine, ya antes, a su hija Angustias que «¿Es decente que una mujer de tu clase vaya con el anzuelo detrás de un hombre el día de la misa de su padre?» ( $L B A: 131)$.

Como ya ha quedado bien refrendado por buena parte de la crítica, Federico García Lorca ha sido considerado, en sus escritos y en la vida, como el «poeta de la contradicción, del juego de opósitos, el poeta de las disyuntivas radicales» (Fernández Montesinos 1989: 21). Desde una perspectiva estrictamente teatral, su obra se puede caracterizar en términos de una lucha constante para fusionar las fuerzas opuestas de la existencia humana hacia el final de «mística Unión» (Maurer 1994: 32-34); un ardiente deseo por parte del poeta de alcanzar, a través del arte, el estado eterno, donde los lados espirituales y materiales (carnales) de la vida pueden coexistir para siempre en armonía comunal (Maurer 1994: 34-38). Sin embargo, desde un punto de vista social, Lorca apunta con frecuencia a estas mismas fuerzas opuestas de la condición humana para subrayar las deficiencias morales y éticas de la sociedad española. Por tanto, ese sesgo cervantino Alberti lo había llevado a un debate político, pero Lorca lo llevó a un debate existencial.

En el amplio recorrido bio-bibliográfico que hizo Ian Gibson (1987) en su célebre libro, en dos volúmenes, sobre García Lorca, dejó bien clara la admiración que el poeta granadino siempre tuvo por la obra de Cervantes y así lo 
corrobora en esta cita que resulta altamente sintomática e ilustrativa de cómo veía Lorca a los clásicos que más leyó:

El 7 de octubre estaba programada una representación de La vida es sueño en el corral del Carbón - antigua fonda árabe-, pero debido al mal tiempo esta se dio en el teatro Isabel la Católica, teniendo, según la prensa local, un extraordinario éxito. Al parecer Lorca en el escenario fue recibido, como era de esperar en tales circunstancias, con una ovación clamorosa. En sus palabras de presentación el poeta leyó su disertación acerca de Calderón y Cervantes - expresión máxima de la polaridad española entre lo espiritual y lo humano-, y habló de la satisfacción que sentía al encontrarse en un teatro donde, de niño, se había asomado, atónito, a los «poemas dramáticos nacionales», poemas que ahora él tenía el honor de resucitar (Gibson 1987: 215-216).

Esa resurrección a la que alude el poeta la hizo a través de La Barraca. En el caso concreto de Cervantes, según el estudio, completo, de Luis Sáenz de la Calzada (1976: 60-65) y Javier Huerta Calvo (2016) entre otros, en el repertorio de la compañía teatral solo estaban los entremeses La cueva de Salamanca, La Guardia Cuidadosa, El retablo de las maravillas y la adjudicada obra Los Habladores, pero no existe mención alguna de La destruición de Numancia ni del proyecto por representarla, con lo que su acercamiento a la obra, como atestigua Francisco García Lorca (1980: 187-188), sí se dio, pero por voluntad estrictamente personal, por su pasión por el autor de $E l$ Quijote. Más allá de esto - y que no limita ese concepto tan vago de influencia-, el texto cervantino influye en el del poeta granadino muy claramente, pero no tanto en lo superficial o superfluo del texto (tampoco es una adaptación), sino más bien en los constituyentes más elementales, considerando que existen ciertas estructuras que, dramáticamente, se repiten y articulan funcionalmente.

El nombre de Pepe el Romano es, sin duda, uno de los mejores ejemplos: Josephs y Caballero (1996: 125) señalan en su edición que «se basa en el personaje real Pepe de Romilla. Romilla la Nueva es un pueblo cercano a Valderrubio, a unos 12 kilómetros al sur», lo que limitaría sobremanera la lectura simbólica del mismo, como los propios autores reconocen y defienden, y que la mayoría de sucesos ocurrieron en realidad pues García Lorca quiso llevar esta historia a los escenarios con algunas pinceladas simbólicas que deformaran la propia historia y no la convirtiera en simple crónica social teatralizada. Pero nada más lejos de la realidad a nuestro entender sin negarles su lógica porción de acierto: es muy posible hacer una lectura en clave de Pepe el Romano, cuya sombra, gigante, vasta y tiránica, llena, al principio, de prestigio social (frente a los Humanes, por ejemplo), aprisiona todavía más a las mujeres de la casa, a pesar de que no tiene presencia en escena y ni voz, como buen personaje latente. Se asemeja, por el orgullo que muestra a lomos de su caballo y por la soberbia con la que actúa siempre, al Cipión cervantino, con la salvedad de que uno es un héroe de guerra y el otro un simple 
hombre movido por su instinto sexual y sabedor — de ahí su figuración tiránica- de que no habrá mano firme contra su conducta invasora. En este sentido, y sin contradecir tampoco la interpretación francamente acertada de John Gabriele (2013), sí nos parece altamente simbólico su nombre pues responde a la abstracción de un asedio, del mismo modo que Cervantes daba entrada a personajes alegóricos que mostraban la evolución y la tensión de ese mismo asedio llevado a cabo por los romanos y Alberti le había llevado hasta los pies de fascismo a la italiana. No puede reducirse, exclusivamente, a una lectura política ni de Bernarda ni de Pepe, como sí hizo Alberti con su general, pero la función que desempeña viene a coincidir con la del opresor, pues equivocadamente se habla de la figura de la madre como la opresora $-\mathrm{y}$ en esto sí discutimos con la lectura realizada por Cecilia Townsend (2003) en varias y recurrentes ocasiones - cuando lo que realiza, realmente, es una acción, equivocada y obstinada, de defensa sobre un modelo de conducta impuesto y subyugante (Doménech 2008: 170-172). Otro aspecto —aunque ya menor- de coincidencia entre los dos textos es que finalizan con la muerte del personaje más joven: Bariato y Adela que remite, por otro lado, a la Antígona de Sófocles.

Si tradicionalmente se ha valorado la libertad como tema axial en la obra cervantina, en cambio, también se ha considerado su negación otra ruta marcada por su obra en general. Caso semejante encontramos en García Lorca y su famosa trilogía trágica de la tierra. E incluso su reivindicación de lo trágico para pulsar las dormidas emociones del público también eran coincidentes, de tal modo que sendos autores no cumplirán sensu estricto buena parte de los postulados de la tragedia clásica (Camacho Rojo 2006), porque igualmente en los dos casos esas modulaciones de la tragedia llevadas a tal efecto vinieron motivadas por esa misma libertad que constantemente les llevó a continuar, debatir o matizar su propio concepto trágico. Por ello el propio Lorca afirmaba en 1933 a Pablo Suero que «el teatro, para volver a adquirir su fuerza, debe volver al pueblo, del que se ha apartado [...]. El teatro es además cosa de poetas [...] sin sentido trágico no hay teatro [...] y del teatro de hoy está ausente del sentido trágico» (OC, II: 1021). Y es que la tragedia, tan ampliamente estudiada en los dos $\operatorname{casos}^{35}$, ya nos invita al sacrificio, al esfuerzo del espíritu humano por aclarar y entender el valor último de la existencia que estaba regida por poderes metafísicos. Tanto Cervantes como Lorca logran sacar de la acción (fábula) ese designio divino y llevarlo hasta la voluntad humana, por lo que se nos presentan personajes que están sujetos a un conflicto abierto con la libertad, donde tan libres son de sus actos como

35. Resulta improductivo, a nuestro entender, hacer ahora una lista que ponga sobre el tapiz del trabajo la enorme cantidad de estudios publicados en torno a la tragedia de Federico García Lorca y de Miguel de Cervantes respectivamente. En todo caso, son muy destacables los trabajos de Ricardo Doménech (2008), Luis González del Valle (1975), la visión general de Gwynne Edwards (1983) en torno a la figura lorquiana y los estudios, obviamente, de Stanislav Zimic (1992), Marie Laffranque (1967) y de Jesús G. Maestro (2004) para la obra cervantina. 
esclavos de sus consecuencias, que pueden ser positivas (véase el caso del pueblo numantino) o negativas, como en el caso del general Escipión o del conjunto de la casa de Bernarda. Y es que esto nos lleva nuevamente a otro aspecto fundamental para las dos obras: la predeterminación del destino.

Tengamos presente que la tragedia contemporánea pone ese daimón dentro de nosotros mismos, con su imposición como determinación personal, lo que nos convierte en víctimas de nuestra libertad, de ahí lo paradójico del proceso y su ridiculización posterior. Lo decía Yerma, por ejemplo, en la tragedia de mismo título, cuando su oráculo interior le anunciaba su sequedad y muerte interna en el turbio futuro de su matrimonio, es decir, la fatalidad de su obstinación. Y es que la necesidad, que mueve a la acción, arranca de lo hondo, como a Merandro le impulsaba a ir en busca de comida para Lira, o a Leonicio, asentado fuertemente sobre el importante valor de la amistad, le lleva a acompañarle a tal suicida aventura. Tal caso ocurre con una Adela que sale al encuentro de su propia fatalidad y que acepta, claro está, pues forma parte de una elección tomada desde la libertad y desde la necesidad más honda que la ata, en cambio, a la esclavitud de sus instintos, de ahí que diga: «Ya no me importa, pero yo me iré a una casita sola donde él me verá cuando quiera, cuando le venga en gana» ( $L B A$ : 196). Una justicia cruel que la política sí debía regular y quizá aquí estribe el fracaso de la visión politizada del teatro lorquiano.

La acción, pues, se sitúa tanto dentro como fuera del héroe, así que la causa está también en su naturaleza, y eso es lo que debe regir la política (el sustituto, como afirma Fernando Savater [1982: 53-69], de la tragedia), que restringe las libertades de cada cual siempre en busca de una armonización colectiva pues ¿qué hubiera sido de Numancia si Bariato no hubiera decidido libremente lanzarse al vacío y pensar solo en sí mismo? La muerte no hubiera sido trágica, sino innecesaria y, por tanto, ridiculizada. Lo trágico, pues, estriba en esa libertad de acción, no en su determinación.

También, la imagen del opresor, como tal, en acecho vincula los dos textos: ¿por poder o por deseo? Quizá por las dos cosas, pues su Cipión debe preservar su fama y Bernarda (primera figura opresora) también, aunque Adela haya renunciado a ella, de ahí que afirme ante su hermana Martirio:

\footnotetext{
Ya no aguanto el horror de estos techos después de haber probado el sabor de su boca. Seré lo que él quiera que sea. Todo el pueblo contra mí, quemándome con sus dedos de lumbre, perseguida por los que dicen que son decentes, y me pondré la corona de espinas que tienen las que son queridas de algún hombre casado (LBA: 195).
}

Porque Pepe (segunda figura opresora), como Cipión, no se conforma con el vasallaje de Angustias: parece querer sentir el placer de invadir, de erigirse como héroe de la contienda y en ese paso en falso comienza a construir su propia derrota, pues quedará sin matrimonio con Angustias, con la que iba a tener buen casamiento, aunque esto nunca sea dicho explícitamente. Y esta 
visión que aquí proponemos resulta diferente a las interpretaciones que se han hecho de la obra y que justifican, no sabemos si lo suficiente, este primer apunte crítico al respecto.

Tampoco es azaroso, si seguimos esa senda comparativa, que en el texto de Lorca las mujeres tomen la palabra a pesar de la insistencia del silencio dictado u ordenanza restrictiva que cierra, del mismo modo, la propia obra en boca de Bernarda. En la obra cervantina son las mujeres las que le dicen a los cegados hombres que son incapaces de ver más allá de su instinto guerrero $^{36}$, como tan excelentemente ha estudiado Verónica Ryjik (2006), quien a su vez vio dicha intervención como el momento crucial del texto. Podríamos incluso afirmar que estamos ante la anagnórisis de la obra, pues marcará el paso de la ignorancia al conocimiento entre los personajes:

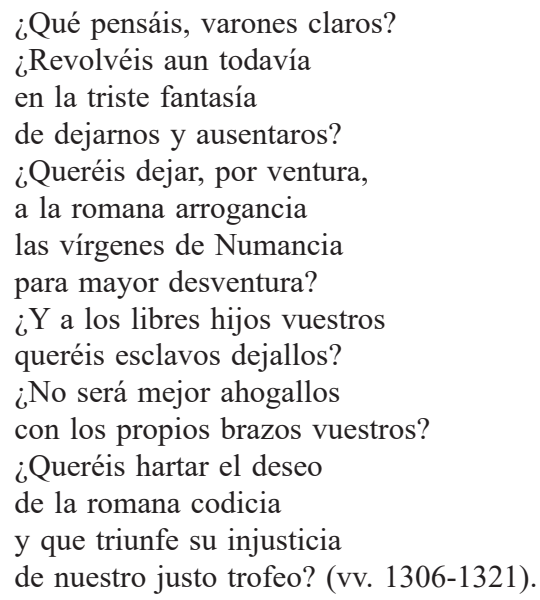

Pero las mujeres lorquianas parecen ser el reverso de esa gran victoria implícita de las numantinas: una imagen en el espejo que devuelve una involución dañina y opresora, de ahí que Magdalena afirme «Malditas sean las mujeres» (LBA: 129), o La Poncia denuncie «la conversación que traían los hombres, que, como siempre, no se puede oír» ( $L B A: 132)$. Una actitud que contrastaba con ciertas conductas más secretas donde la mujer dominaba el ámbito privado de la casa, como luego más tarde explicaba la propia Poncia cuando contaba que golpeaba a su propio marido: "Yo tengo la escuela de tu madre. Un día me dijo no sé qué cosa y le maté todos los colorines con la mano del almirez» (LBA: 152). Poder que las jóvenes reclutadas en la casa habían aplaudido con un utópico y esperanzado "¡Así debían ser todas las mujeres!» (LBA: 152) en boca de Magdalena. Y sin embargo, toda esa autoridad de la mujer vendría a caer en olvido cuando Bernarda, más tarde, le aconsejaba a su hija Angustias: «No le debes preguntar [a Pepe]. Y cuando te 
cases, menos. Habla si él habla y míralo cuando te mire. Así no tendrás disgustos» (LBA: 183). Estas son las mujeres numantinas sin voz ni voto, ni tampoco presencia real ante su destino, son solo su reverso, su derrota más amarga.

Decía Luis García Montero (1996: 11) que tanto García Lorca como Alberti son dos poetas que marcan la perfecta combinación entre una vanguardia pujante y una tradición emergente, pero también entre una ideología en barrena y otra a la que apenas le estaban creciendo las raíces. Y no solo eso, sino que además ejemplificaron la tragedia no como artefacto de laboratorio teatral, sino como muestrario de las pasiones frustradas y de la lucha humana en su reconstrucción como esperanza, como identidad (González del Valle 1975: 101-168). Y como telón de fondo la inestimable obra de Cervantes: ya no tanto como modelo en sí, sino más bien como vía, del mismo modo que hablamos de la influencia quijotesca, por ejemplo, en la construcción de la novela contemporánea. Sirvan estas líneas, pues, para corroborar que fue notoria la influencia de la tragedia cervantina en el texto de García Lorca, aunque no se haya apuntado este fenómeno en ninguno de los estudios que hemos cotejado, del mismo modo que nos hacemos eco de la manipulación, muy condicionada por su circunstancia, que hizo Alberti del mismo texto, sobrepasando los agentes funcionales y modificándolos sustancialmente para darle una lectura politizada que, sin embargo, no perdía la enjundia cervantina de fondo. Más allá de las especulaciones sobre algunas concretas y circunstanciales influencias cabría no entrar ya que no es ahí donde queda el magisterio del clásico, pues como afirmara otro de los autores del 27, Pedro Salinas, toda época coloca sobre el libro clásico «su propia interpretación» y eso es, a fin de cuentas, lo que hicieron Alberti y García Lorca con La destruición de Numancia de Cervantes.

\section{FUENTES}

Alberti, Rafael (1933). La poesía popular en la lírica española contemporánea. IenaLeipzig: W. Gronau Verlag.

Alberti, Rafael (1975). Numancia. Madrid: Ediciones Turner.

Alberti, Rafael (2003). Numancia. Tragedia en tres jornadas. Edición de Eladio Mateos y Gonzalo Santonja (ed.). Obras completas. Teatro I. Barcelona: Seix Barral-Sociedad Estatal de Conmemoraciones Culturales, pp. 537-599; y pp. 706-710.

Bergamín, José (1979). Calderón y cierra España y otros ensayos disparatados. Barcelona: Planeta.

Cernuda, Luis. (2002). Prosas II, Derek Harris y Luis Maristany (ed.). Madrid: Siruela.

Cervantes, Miguel de (1994). La destruición de Numancia, Alfredo Hermenegildo (ed.) Madrid: Castalia.

Cervantes, Miguel de (2005). Entremeses, Nicholas Spadaccini (ed.). Madrid: Cátedra.

Cervantes, Miguel de (2009). Tragedia de Numancia, Alfredo Baras (ed.). Zaragoza: Prensas Universitarias de Zaragoza. 
El Mono Azul 19 (10 de junio de 1937); 20 (17 de junio de 1937); 36 (14 de octubre de 1937); 39 (4 de noviembre de 1937); 42 (25 de noviembre de 1937); 43 (2 de diciembre de 1937); 44 (9 de diciembre de 1937); 45 (mayo de 1938).

El Sol 185 (28 de diciembre de 1937); 186 (29 de diciembre de 1937).

García Lorca, Federico (1980). Obras Completas. Vol. II. Edición de Arturo del Hoyo. Madrid: Aguilar.

García Lorca, Federico (1980b). Prosa. Madrid: Alianza Editorial.

García Lorca, Federico (1994). Obras Completas. Vol VI. Edición de M. García Posada. Madrid: Akal.

García Lorca, Federico (1997). Obras Completas. Vol III. Edición de M. García Posada. Barcelona: Galaxia Gutemberg-Círculo de Lectores.

García Lorca, Federico (1996). La casa de Bernarda Alba. A. Josephs y Juan Caballero (ed.). Madrid: Cátedra.

Machado, Antonio (1937). «Sobre la defensa y la difusión de la cultura. Discurso pronunciado en Valencia en la sesión de clausura del Congreso Internacional de Escritores. El poeta y el pueblo. Los milicianos de 1936», Hora de España. 8 (agosto), pp. 11-19.

Revista Cubana (1935). vol. II. 4-5-6, La Habana.

\section{BIBLIOGRAFÍA CITADA}

Alonso, Dámaso (1961). La lengua poética de Góngora. Madrid: CSIC

Alonso, Dámaso (1968). Del Siglo de Oro a este siglo de siglas. Madrid. Gredos.

Aragonés, Juan Emilio (1977). «El teatro de los poetas del 27», La Estafeta Literaria. 618-619, p. 58-62.

Arlandis, Sergio (2016). «El teatro de Miguel de Cervantes visto por el 27: algunas líneas de revisión (I)», E/Humanista. 34, pp. 548-565. <http://www.ehumanista.ucsb.edu/ sites/secure.1sit.ucsb.edu.span.d7_eh/files/sitefiles/ehumanista/volume34/30\%20 ehum34.arlandis.pdf>.

Armas, Frederick A. de (1974). «Classical Tragedy and Cervantes' La Numancia», Neophilologus. LVIII, pp. 34-40.

Astrana Marín, Luis (1927). «El fracasado centenario de Góngora», Argos. 7, pp. 15-21.

Asún, Raquel (1986). «1927 y la literatura clásica: presencia de Fray Luis de León», en VV. AA., Studia in honorem Martín de Riquer. I. Barcelona: Quaderns Crema, pp. 201234.

Aub, Max (1956). «La Numancia de Cervantes», La Torre. 14, pp. 99-111.

Azcue, Verónica (2002). El drama del honor ante el siglo XX. Madrid: Pliegos.

Aznar Soler, Manuel (1997). «El teatro español durante la II República (1931-1939)», Monteagudo. 2, pp. 45-57.

Baras Escolá, Alfredo (2009). «Estudio preliminar», en Miguel de Cervantes, Tragedia de Numancia. Zaragoza: Prensas Universitarias de Zaragoza, pp. 13-54.

Baras Escolá, Alfredo (2014). «Las dos Numancias de Alberti», E/Humanista/Cervantes. 3, pp. 243-273. Accesible en: http://www.ehumanista.ucsb.edu/sites/secure.lsit.ucsb. edu.span.d7_eh/files/sitefiles/cervantes/volume3/ehumcerv3.baras.pdf [Fecha de consulta: $18-1-2015]$.

Calvo Carilla, José L. (1992). Quevedo y la generación del 27. Valencia: Pretextos.

Camacho Rojo, J. María (ed.) (2006). La tradición clásica en la obra de Federico García Lorca. Granada: Universidad de Granada. 
Canavaggio, Jean (1983). «García Lorca ante el entremés cervantino: el telar de La zapatera prodigiosa», en Luciano García Lorenzo (ed.), El teatro menor en España a partir del Siglo XVI, Anejos de la Revista Segismundo, 4. Madrid: CSIC, pp. 141-153.

Canavaggio, Jean (2004). «Numance de Jean-Louis Barrault: el París de 1937 ante un Cervantes inédito», en José M. Díez Borque y J. Alcalá Zamora (coord.), Proyección y significados del teatro clásico español. Homenaje a Alfredo Hermenegildo y Francisco Ruiz Ramón. Madrid, mayo de 2003. Madrid: Sociedad Estatal para la Acción Cultural Exterior, pp. 173-183.

Casalduero, Joaquín (1966). Sentido y forma del teatro de Cervantes. Madrid: Gredos.

Castillo, Marta (2008). El teatro de García Lorca y la crítica. Recepción y metamorfosis de una obra dramática (1920-1960). Málaga: Centro Cultural Generación del 27.

Chabás, Juan (1937). «Nuevo Gran Teatro del Mundo», El Mono azul. 31 (2 de septiembre), p. 1.

Dehennin, Elsa (1962). La résurgence de Góngora et la Génération poétique de 1927. Paris: Didier.

Diago, Nel (2012). «El estreno de La casa de Bernarda Alba en Buenos Aires en la prensa argentina de la época», Anales de la Literatura Española Contemporánea. 37, 2, pp. 147-169.

Díaz Fernández, José (1985). El nuevo romanticismo: polémica de arte, política y literatura. Madrid: Editorial José Esteban Editor. Primera edición de 1930.

Díez de Revenga, Francisco J. (2003). La tradición áurea. Sobre la recepción del Siglo de Oro en poetas contemporáneos. Madrid: Biblioteca Nueva.

Doménech, Ricardo (1972). «Introducción al teatro de Rafael Alberti», Cuadernos Hispanoamericanos. 259, pp. 95-126.

Doménech, Ricardo (2008). García Lorca y la tragedia española. Madrid: Fundamentos.

Dougherty, Dru y Lima, Robert (1984). 2 ensayos sobre el teatro español de los 20. Murcia: Universidad de Murcia.

Edwards, Gwyne (1983). El teatro de Federico García Lorca. Madrid: Gredos.

Egido, Aurora (2009). El Barroco de los modernos. Despuntes y pespuntes. Valladolid: Cátedra Miguel Delibes.

Fernández Montesinos, Manuel (1989). «Variantes significativas en algunos borradores de Federico García Lorca», en Laura Dolfi (ed.), L'imposible/posible di Federico García Lorca. Roma: Edizioni Scientifiche Italiane, pp. 21-32.

Forradillas, Joaquín (ed.) (1978). Federico García Lorca. La zapatera prodigiosa. Salamanca: Almar.

Gabriele, John P. (2013). «A Case of Intertextual Discourse: Ernesto Caballero's Pepe el Romano and Federico García Lorca's La casa de Bernarda Alba», Journal of Iberian and Latin American Studies. Vol. 19, 2, pp. 117-137, doi: https://doi.org/10.1080/147 01847.2013.867390.

Gaos, Vicente (1989). Cervantes. Novelista, dramaturgo, poeta. Barcelona: Planeta.

García Lorca, Francisco (1980). Federico y su mundo. Madrid: Alianza.

García Montero, Luis (1996). La palabra de Ícaro. Estudios literarios sobre García Lorca y Alberti. Granada: Universidad de Granada.

Gibson, Ian (1987). Federico García Lorca 2. De Nueva York a Fuente Grande 1929-1936. Barcelona: Grijalbo.

Gibson, Ian (1998). Vida, pasión y muerte de Federico García Lorca. Barcelona: Plaza \& Janés.

González Briz, M. ${ }^{a}$ de los Ángeles (2007). «La Numancia de Rafael Alberti y M. ${ }^{a}$ Teresa León ¿Palimpsesto o copia?», en Cervantes entre dos siglos de Oro: de La Galatea al 
Persiles. Anuario de Estudios Cervantinos, 3. Vigo: Academia del Hispanismo, pp. 83-92.

González del Valle, Luis (1975). La tragedia en el teatro de Unamuno, Valle-Inclán y García Lorca. New York: Eliseo Torres \& Sons.

Hermans, Hub (1989). El teatro político de Rafael Alberti. Salamanca: Publicaciones Universidad de Salamanca.

Hermenegildo, Alfredo (1993). «El parapeto intertextual albertiano y el compromiso de la guerra civil», Anthropos. 148, pp. 61-64.

Hermenegildo, Alfredo (1994). «Introducción», en Miguel de Cervantes, La destruición de Numancia. Madrid: Castalia, pp. 9-39.

Honig, Edwin (1964). «Reality and Realism in Cervantes and Lorca», New Mexico Quaterly. 34, pp. 31-47.

Honig, Edwin (1974). García Lorca. Barcelona: Editorial Laia.

Huerta, Teresa (1995). «Tiempo de iniciativa en la Fuenteovejuna de Federico García Lorca», Hispania. 78, pp. 480-487, doi: https://doi.org/10.2307/345824.

Huerta Calvo, Javier (2016). «Cervantes y Lorca: La Barraca», Don Galán. Revista Audiovisual de Investigación Teatral-CDT. 5, pp. 1-11. Accesible en: http://teatro.es/ contenidos/donGalan/donGalanNum5/pagina.php?vol=5\&doc=1_2\&cervantes-lorcala-barraca\&javier-huerta-calvo [Fecha de consulta: 2-2-2016].

Jiménez Gómez, Hilario (2003). Lorca y Alberti. Dos poetas en un espejo (1924-1936). Madrid: Biblioteca Nueva-Diputación de Cáceres.

Jiménez León, Marcelino (2001). «Rafael Alberti y La Numancia de Cervantes», en Antonio Bernat Vistarini (ed.), Volver a Cervantes. Actas del IV Congreso Internacional de la Asociación de Cervantistas (Lepanto, 1-8 de octubre de 2000). Vol. II. Palma: Universitat de les Illes Balears, pp. 1177-1200.

Jimeno, Alfredo y De la Torre, J. Ignacio (2005). Numancia, símbolo e historia. Madrid: Akal.

Josephs, Allen y Caballero, Juan (1996). «Introducción y notas», en Federico García Lorca, La casa de Bernarda Alba. Madrid: Cátedra, pp. 11-114.

Laffranque, Marie (1967). Les idées esthétiques de Federico García Lorca. Paris: Centre de Recherches Hispaniques, Institut d'Études Hispaniques.

Lewis-Smith, Paul (1987). "Cervantes' Numancia as Tragedy and as Tragicomedy», Bulletin of Hispanic Studies. LXIV, pp. 15-26, doi: https://doi.org/10.3828/bhs.64.1.15.

Maestro, Jesús G. (2003). «El triunfo de la heterodoxia. El teatro de Cervantes y la literatura europea», Theatralia. Revista de poética del teatro. «El teatro de Miguel de Cervantes». 5, pp. 19-52.

Maestro, Jesús G. (2004). La secularización de la tragedia. Cervantes y «La Numancia». Madrid: Ediciones Clásicas-University of Minnesota.

Maestro, Jesús G. (2013). Calipso eclipsada. El teatro de Cervantes más allá del siglo de oro. Madrid: Verbum.

Marrast, Robert (1957a). Cervantes dramaturge. Paris: L'Arche.

Marrast, Robert (1957b). «Deux adaptations de la Numance de Cervantès», en Jean Jacquot y André Veinstein (ed.), La mise es scène des oeuvres du passé. Paris: CNRS, pp. 60-65.

Marrast, Robert (ed.) (1964). Rafael Alberti. Prosas encontradas (1924-1942). Madrid: Ayuso.

Marrast, Robert (1984). «Introducción», en Miguel de Cervantes, El cerco de Numancia. Madrid: Cátedra. pp. 7-69.

Marrast, Robert (2003) «María Teresa León y el teatro en Madrid durante la Guerra Civil», en Gonzalo Santonja (ed.), Homenaje a María Teresa León en su centenario. Madrid: Sociedad Estatal de Conmemoraciones Culturales, pp. 245-251. 
Martín Otín, J. Antonio (2008). La desesperación del té (27 veces Pepín Bello). Valencia: Pretextos.

Martínez Sáura, Santos (1998). Espina, Lorca, Unamuno y Valle-Inclán en la política de su tiempo. Madrid: Ediciones Libertarias.

Maurer, Christopher (1994). «Introducción», en Federico García Lorca, Prosa inédita de juventud. Madrid: Cátedra, pp. 7-84.

McDermott, Patricia (1993). «Dramatic Uses of a Cervantine Model», en J. Macklin (ed.), After Cervantes. A Celebration of 75 Years of Iberian Studies at Leeds. Leeds: Trinity and All Saints, pp. 247-276.

Monleón, José (1992). «Tradición y dictadura: Valle-Inclán y Lorca», en Dru Dougherty y María Francisca Vilches de Frutos (ed.), El teatro en España entre la tradición y la vanguardia (1918-1939). Madrid: CSIC-Fundación García Lorca, pp. 375-383.

Morelli, Garbriele (2001). Gerardo Diego y el tercer centenario de Góngora. Valencia: Pretextos.

Morris, C. B. (1988). Una generación de poetas españoles (1920-1936). Madrid: Gredos.

Pitollet, Camille (1937). «La Numancia au théâtre Antoine», Bulletin Hispanique. 39, 4, pp. 405-410, doi: https://doi.org/10.3406/hispa.1937.2788.

Oliva, César (2003). «La práctica escénica de María Teresa León», en Gonzalo Santonja (ed.), Homenaje a María Teresa León en su centenario. Madrid: Sociedad Estatal de Conmemoraciones Culturales, pp. 253-265.

Rodríguez Fischer, Ana (ed.) (1989). Miguel de Cervantes y los escritores del 27. Anthropos. Suplemento 16.

Rodríguez-Solás, David (2016). «La Barraca, 1933: el giro lopiano de García Lorca», Anuario Lope de Vega. texto, literatura, cultura. XXII, pp. 200-216, doi: http://dx.doi. org/10.5565/rev/anuariolopedevega.148.

Rosales, Luis (1997). Estudios sobre el Barroco, vol. I. Madrid: Editorial Trotta.

Rozas, Juan M. (1974). La generación del 27 desde dentro. Madrid: Alcalá-Límina.

Ryjik, Verónica (2006). «Mujer, alegoría e imperio en el drama de Miguel de Cervantes, El cerco de Numancia», Anales Cervantinos. 38, pp. 203-219.

Sáenz de la Calzada, Luis (1976). La barraca. Teatro universitario. Madrid: Revista de Occidente.

Salaün, Serge (1996). «Política y moral en el teatro comercial a principios del siglo XX», en María F. Vilches de Frutos y Dru Dougherty (coord.), «Teatro, sociedad y politica en la España del siglo XX». Boletín de la Fundación Federico García Lorca. 19-20, pp. 27-47.

Sánchez Castañer, Francisco (1976). «Representaciones teatrales de La Numancia de Cervantes en el siglo XX», Anales Cervantinos. 15, pp. 3-18.

Sánchez García, Remedios (2012). «Teatro para el pueblo o despertar al dormido. A propósito del compromiso lorquiano con La Barraca», Anuario de Estudios Filológicos. XXXV, pp. 201-213.

Savater, Fernando (1982). La tarea del héroe. Madrid: Taurus.

Smerdou, Margarita (1991). «Cervantes en la Generación del 27 (esbozo de un libro)» en VV. AA., Actas del II Coloquio Internacional de la Asociación de Cervantistas. Alcalá de Henares 6-9 de noviembre de 1989. Vol I. Barcelona: Anthropos, pp. 273-280.

Soria Olmedo, Andrés (ed.) (1997). ¡Viva don Luis! 1927. Desde Góngora a Sevilla. Madrid. Residencia de Estudiantes.

Soria Olmedo, Andrés (2016). «De Lorca a Lope», Anuario Lope de Vega. Texto, literatura, cultura. XXII, pp. 287-309, doi: http://dx.doi.org/10.5565/rev/anuariolopedevega.149. 
Stroud, Matthew D. (1981). «La Numancia como auto secular», en Manuel Criado del Val (ed.), Cervantes, su obra y su mundo. Madrid: EDI-6, pp. 303-307.

Torres Monreal, Francisco (1994). «Cervantes en el teatro francés 1935-1965», en VV. AA., Cervantes. Estudios en la víspera de su centenario. Kassel: Reichenberger, vol. II, pp. 605-646.

Torres Nebrera, Gregorio (1982). El teatro de Rafael Alberti. Madrid: SGEL.

Torres Nebrera, Gregorio (2009). El posible imposible teatro del 27. Sevilla: Renacimiento.

Townsend, Cecilia (2003). «Parallel Worlds in The house of Bernarda Alba and Like Water of Chocolates», en Zenia Sacks (ed.), The Hispanic Connections. Spanish and SpanishAmerican Literature in the Arts of the World. New York: Greenwood ed. - Hofstra University, pp. 375-383.

Tuveson, Ernest L. (1949). Millenium and Utopia. A Study in the Background of the Idea of Progress. Berkeley: University of California Press.

Valbuena Prat, Ángel (1979). El teatro español en su Siglo de Oro. Barcelona: Planeta.

Vivar, Francisco (2004). La Numancia de Cervantes y la memoria de un mito. Madrid: Biblioteca Nueva.

Wahnón, Sultana (1995). «La recepción de García Lorca en la España de la posguerra», Nueva Revista de Filología Hispánica. XVIII, 2, pp. 409-431, doi: https://doi.org/ 10.24201/nrfh.v43i2.1884.

Zimic, Stanislav (1992). El teatro de Cervantes. Madrid: Castalia.

Recibido: 20 de febrero de 2015

Aceptado: 31 de marzo de 2017 